Key Words:

MST

Actinides

Permanganate

Strontium

\title{
Demonstration of MST and Permanganate Efficiency on Removal of Actinides and Strontium from Savannah River Site High Level Waste
}

\author{
T. B. Peters \\ S. D. Fink \\ D. T. Hobbs \\ M. A. Norato \\ D. D. Walker
}

March 11, 2003

Westinghouse Savannah River Company

Savannah River Site

Aiken, SC 29808

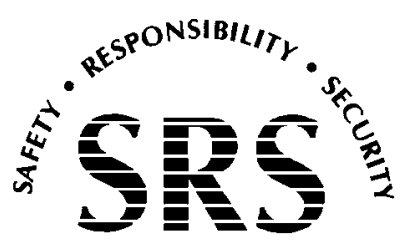

SAVANNAH RIVER SITE

Prepared for the U.S. Department of Energy Under

Contract Number DE-AC09-96SR18500 
This document was prepared in conjunction with work accomplished under Contract No. DE-AC09-96SR18500 with the U. S. Department of Energy.

\section{DISCLAIMER}

This report was prepared as an account of work sponsored by an agency of the United States Government. Neither the United States Government nor any agency thereof, nor any of their employees, makes any warranty, express or implied, or assumes any legal liability or responsibility for the accuracy, completeness, or usefulness of any information, apparatus, product or process disclosed, or represents that its use would not infringe privately owned rights. Reference herein to any specific commercial product, process or service by trade name, trademark, manufacturer, or otherwise does not necessarily constitute or imply its endorsement, recommendation, or favoring by the United States Government or any agency thereof. The views and opinions of authors expressed herein do not necessarily state or reflect those of the United States Government or any agency thereof.

This report has been reproduced directly from the best available copy.

Available for sale to the public, in paper, from: U.S. Department of Commerce, National Technical Information Service, 5285 Port Royal Road, Springfield, VA 22161, phone: (800) 553-6847, fax: (703) 605-6900

email: orders@ntis.fedworld.gov

online ordering: http://www.ntis.gov/help/index.asp

Available electronically at http://www.osti.gov/bridge

Available for a processing fee to U.S. Department of Energy and its contractors, in paper, from: U.S. Department of Energy, Office of Scientific and Technical Information, P.O. Box 62, Oak Ridge, TN 37831-0062,

phone: (865)576-8401,

fax: (865)576-5728

email: $\underline{\text { reports@ adonis.osti.gov }}$ 
This page intentionally left blank 
WSRC-TR-2002-00355

\section{List of Abbreviations}

$\begin{array}{ll}\text { ADS } & \text { Analytical Development Section } \\ \text { AMP } & \text { Ammonium molybdophosphate } \\ \text { ARP } & \text { Actinide Removal Process } \\ \text { DDI } & \text { Distilled Deionized water } \\ \mathrm{DF} & \text { Decontamination Factor (= starting concentration/ending concentration) } \\ \mathrm{DL} & \text { Detection Limit } \\ \mathrm{DU} & \text { Depleted Uranium } \\ \mathrm{H}_{2} \mathrm{O}_{2} & \text { Hydrogen Peroxide } \\ \mathrm{HLW}^{-} & \text {High Level Waste } \\ \mathrm{MnO}_{4}- & \text { Permanganate } \\ \mathrm{MST} & \text { Monosodium Titanate } \\ \mathrm{Np} & \text { Neptunium } \\ \mathrm{NTU} & \text { Nephlometric Turbidity Unit } \\ \text { Pu } & \text { Plutonium } \\ \text { PuTTa } & \text { Plutonium thenoyl trifluoroacetone scintillation } \\ \text { RADICP-ES } & \text { Radiological inductively-coupled plasma emission spectroscopy } \\ \text { RADICP-MS } & \text { Radiological inductively-coupled plasma mass spectroscopy } \\ \text { SRS } & \text { Savannah River Site } \\ \text { SRTC } & \text { Savannah River Technology Center } \\ \text { Sr } & \text { Strontium } \\ \text { SWPF } & \text { Salt Waste Processing Facility } \\ \text { U } & \text { Uranium } \\ \text { WAC } & \text { Waste Acceptance Criteria } \\ \text { WPTS } & \text { Waste Processing Technology Section }\end{array}$


WSRC-TR-2002-00355

\subsection{Executive Summary}

We conducted a series of four demonstrations to determine the ability of either monosodium titanate (MST) or permanganate $\left(\mathrm{MnO}_{4}^{-}\right)$to remove strontium and actinides from salt solutions, under a variety of conditions. Each of the demonstrations used material derived from actual tank waste. The demonstrations used volumes as large as $68 \mathrm{~L}$ compared to typical prior experiments at $100 \mathrm{~mL}$. Also, the study used, in two experiments, hydraulically scaled mixing conditions to match those of the equipment installed in Building 512-S for the Actinide Removal Process. (Plans call for radioactive commissioning of that facility as early as December 2003.) From the demonstrations, we obtain the following conclusions.

- Plutonium and strontium removal by MST from experiments using simulated and actual waste at volumes from 0.1 to $70 \mathrm{~L}$ and with varying degrees of mixing - from none to fully turbulent - show consistency when evaluated as conventional sorption isotherms. Demonstrations hydraulically scaled to match mixing conditions of the Actinide Removal Process behave consistently with laboratory experiments using orbital shakers. Hence, the complete historical data set provides a reliable basis for predicting behavior within larger equipment.

- Demonstrations hydraulically scaled to match mixing conditions of the Actinide Removal Process indicate good suspension of MST at expected initial operating conditions (i.e., concentrations), but in the absence of sludge. We expect similar suspension with sludge present but recommend additional testing to confirm.

- Strontium removal by MST addition in actual waste demonstrations proved marginal in two demonstrations, failing to meet process requirements for the Salt Waste Processing Facility in one instance, using samples from Tank $37 \mathrm{H}$. We lack an adequate understanding of this poor performance, but believe at this time the weak strontium performance is due to the poor quality of the batch of MST used.

- The use of permanganate showed better removal of strontium than observed for MST in a comparable experiment. The plutonium data contained large variances making a conclusion regarding relative performance to MST impossible. 
WSRC-TR-2002-00355

\subsection{Introduction}

Savannah River Technology Center (SRTC) personnel extensively studied the ability of MST to sorb a variety of elements, such as plutonium $(\mathrm{Pu})$, strontium $(\mathrm{Sr})$, neptunium $(\mathrm{Np})$, and uranium (U). Previous work at SRTC examined the specifics of MST sorption. ${ }^{1,2,3,4,5,6,7,8,9,10}$ The baseline flowsheet for the Salt Waste Processing Facility (SWPF) at the Savannah River Site also uses MST for the removal of radioactive $\mathrm{Sr}, \mathrm{Pu}$ and Np. Hobbs and Walker ${ }^{1}$ studied the adsorption of $\mathrm{Pu}$ and $\mathrm{U}$ onto MST in alkaline solutions. These tests showed that MST would remove the targeted radionuclides from simulated alkaline waste. Continued testing indicates that Pu removal kinetics and $\mathrm{Np}$ capacity of the MST material impacts the size of equipment and waste blending plans for the SWPF. Additionally, calculations suggest the baseline MST process may not achieve the desired decontamination in wastes containing elevated concentrations of $\mathrm{Pu}$ and $\mathrm{Np} .{ }^{11}$ Recent experimental studies explicitly studied the offset between process performance requirements and the actual performance for a near "bounding alpha" waste. ${ }^{12}$

The vast majority of the experiments conducted to date used relatively small volumes of material (e.g., 100-200 mL) and agitated these with orbital shakers. The majority of the experiments used simulated waste with various added radionuclides. In contrast, this work examined MST performance in larger volumes, reaching $68 \mathrm{~L}$, using mixing conditions prototypical of, or at least closer to, those anticipated in either the Actinide Removal Process or the Salt Waste Processing Facility. Two demonstrations used actual waste samples following dilution with caustic to emulate the planned operations in these facilities. Due to the limited availability of actual waste samples, the final two demonstrations recovered the alkaline raffinate from solvent extraction treatment of actual waste and added actinides and strontium for examining MST performance.

\subsection{Experimental Detail}

\subsection{MST Qualification}

SRTC used the same production batch of MST for the experiments below. This material (lot \#MST-96QAB281) is referred to as the TNX (as in "TNX" area) batch in this and prior documents. We obtained a portion of the TNX MST and characterized for use in the tests. Qualification of the material requires two tests: particle size distribution and strontium removal. We measured particle size distribution using a MicroTrac Model SRA150 particle size analyzer. We determined strontium removal in a standard distribution coefficient $\left(\mathrm{K}_{\mathrm{d}}\right)$ test by gamma counting the ${ }^{85} \mathrm{Sr}$ tracer in average SRS simulated waste. ${ }^{13}$ The MST failed both qualification tests (see Appendix 1). The particle size distribution included too many large (e.g., $>17 \%$ larger than 35 micron) and small particles (e.g., $>1.3 \%$ smaller than 1 micron). Similarly, the strontium removal ability proved lower than desired: a DF of $61.0 \pm 2.5$ versus an expected value of 150 . At 
WSRC-TR-2002-00355

the time, the TNX batch of MST was the best batch of material on hand in the quantities needed.

\subsection{Tank 37H/44F MST Strike}

As part of a solvent extraction demonstration in 2001, ${ }^{14}$ SRS Tank Farm personnel provided samples of liquid radioactive waste from Tanks $37 \mathrm{H}$ and $44 \mathrm{~F}$. These tanks are currently inactive and store predominantly salt cake with a layer of concentrated salt solution. Personnel obtained portions of the supernate in 38-L samplers. We received, stored, and processed the samples in the SRTC Shielded Cells in Bldg. 773-A. Personnel combined the two samples in a loosely covered stainless steel tank in Cell Block A. Table 1 summarizes source information for each sample.

Table 1. Origin of Tank 37H and Tank 44F Waste Samples

\begin{tabular}{|l|l|l|}
\hline Source & Tank $37 \mathrm{H}$ & Tank 44F \\
\hline Date Sampled & $10 / 10 / 2000$ & $9 / 27 / 2000$ \\
\hline Identification Number & HTF-358 & (no identification) \\
\hline Date received at SRTC & $10 / 12 / 2000$ & $9 / 28 / 2000$ \\
\hline Approximate volume (L) & 39 & $32^{*}$ \\
\hline
\end{tabular}

* The sampler contained 38L. We transferred approximately 6L to another program and combined the remainder (32L) with the Tank $37 \mathrm{H}$ sample.

Technicians measured the solution density in 50-mL volumetric flasks and weighed them on a balance sensitive to $\pm 1 \mathrm{mg}$. They diluted unfiltered portions $(1 \mathrm{~mL})$ in 99 grams of water or $0.2 \mathrm{M}$ nitric acid and sent for routine analyses. We calculated the exact dilution factors from the density, weight of the nominal 1-mL sample, and weight of the water, assuming ideal mixing of the waste and water. Personnel measured the sodium ion concentration by Inductively Coupled Plasma Emission Spectroscopy (ICP-ES). The sodium ion concentration of the as-received composite solution equaled approximately 12.5 M. However, during transfer of the solution between storage tanks, researchers discovered a mass of crystallized salt at the bottom of the tank. The crystallized material likely formed upon cooling after removal from the waste tanks. The waste tank temperatures are typically $35^{\circ} \mathrm{C}$ and the Shielded Cells temperature generally remains at $25^{\circ} \mathrm{C}$ or less. We added approximately $10 \mathrm{~L}$ of water to dissolve the solids and combined the dissolved solids with the composite sample. A subsequent analysis indicated the sodium ion concentration remained approximately $12 \mathrm{M}$. We transferred a portion of the solution $(\sim 50 \mathrm{~L})$ to a new tank and diluted with 1.6 $\mathrm{M} \mathrm{NaOH}$ solution $(\sim 85 \mathrm{~L})$ to achieve a final sodium ion concentration of $5.6 \mathrm{M}$. Table 2 lists the composition of the diluted salt solution. Personnel determined the plutonium activities by PuTTa analysis, strontium-90 determination occurred by beta scintillation, and 
uranium and neptunium concentrations measurements used Inductively Coupled Plasma Mass Spectroscopy (ICP-MS).

Table 2. Composition of the Tank 37H/44F Waste*

\begin{tabular}{|c|c|c|c|}
\hline Component & Concentration (M) & Component & Activity $(\mathrm{dpm} / \mathrm{mL})$ \\
\hline $\mathrm{Na}^{+}$ & 5.61 & $90 \mathrm{Sr}$ & $2.2 \mathrm{E}+05$ \\
\hline $\mathrm{K}^{+}$ & 0.037 & ${ }^{137} \mathrm{Cs}$ & $1.6 \mathrm{E}+09$ \\
\hline $\mathrm{Cs}^{+}$ & 0.00017 & $238 \mathrm{Pu}$ & $1.7 \mathrm{E}+03$ \\
\hline Free $\mathrm{OH}^{-}$ & 3.9 & $239 / 240 \mathrm{Pu}$ & $<1.2 \mathrm{E}+02$ \\
\hline $\mathrm{NO}_{3}^{-}$ & 0.65 & $238 / 235 \mathrm{U}$ & 4.0 \\
\hline $\mathrm{NO}_{2}^{-}$ & 0.51 & ${ }^{237} \mathrm{~Np}$ & $<0.003$ \\
\hline $\mathrm{AlO}_{2}^{-}$ & 0.17 & & \\
\hline $\mathrm{SO}_{4}^{2-}$ & 0.002 & & \\
\hline $\mathrm{CO}_{3}^{2-}$ & 0.072 & $\mathrm{PH}$ & $>14$ \\
\hline $\mathrm{PO}_{4}^{3-}$ & 0.003 & Density & 1.217 \\
\hline $\mathrm{F}^{-}$ & $<0.01$ & & \\
\hline $\mathrm{Cl}^{-}$ & 0.012 & & \\
\hline $\mathrm{C}_{2} \mathrm{O}_{4}{ }^{2-}$ & $<0.01$ & & \\
\hline $\mathrm{HCO}_{2}^{-}$ & $<0.02$ & & \\
\hline
\end{tabular}

* Table shows composition after dilution with $1.6 \mathrm{M} \mathrm{NaOH}$ to achieve $5.61 \mathrm{M} \mathrm{Na}^{+}$.

To determine if the mixing conditions in the 100-L reactor would be sufficient, researchers performed a MST suspension test. We filled a 100-L cylindrical reactor (Figure 1) with $\sim 67 \mathrm{~L}$ of water and added enough MST (TNX batch) to generate an evenly mixed slurry of $0.52 \mathrm{~g} / \mathrm{L}$ of MST. We allowed the slurry to settle overnight. The next morning we pulled a turbidity sample ("before" sample). We stirred the reactor contents for 20 minutes, using the same type of air driven mixer proposed for the actual experiment. We stirred the contents fast enough to generate a several inch vortex. At this point, personnel collected another turbidity sample ("mixed" sample). Finally, we allowed the contents to settle overnight and pulled another turbidity sample ("overnight" sample). We analyzed each of these turbidity samples in duplicate with an OrbecoHellige Model 965-10A Turbidy meter giving the results shown in Table 3.

Table 3. Turbidity Measurements in a Stirred $100 \mathrm{~L}$ Reactor.

\begin{tabular}{|c|c|c|}
\hline Sample & Analysis 1 (NTU) & Analysis 2 (NTU) \\
\hline Before & 202 & 191 \\
\hline Mixed & 457 & 461 \\
\hline Overnight & 157 & 160 \\
\hline
\end{tabular}


The data clearly indicates that solids-settling occurs in the absence of active mixing. The turbidity "Mixed" sample results are consistent with previous work by Martino that reports a turbidity measurement of $452 \pm 19 \mathrm{NTU}$ for a suspension of $0.55 \mathrm{~g} / \mathrm{L}$ of MST in a salt solution. ${ }^{15}$ In addition, during the mixing stage of this test, we collected a sample by dragging the bottom of the tank with a small plastic scoop. Visual examination of the scoop showed no accumulated solids. Therefore, we conclude that the agitator fully suspended the MST in the vessel.

As part of the original solvent extraction demonstration, ${ }^{14}$ researchers treated the Tank $37 \mathrm{H} / 44 \mathrm{~F}$ composite sample in two equal sized batches ( $\sim 66 \mathrm{~L}$ each). Each MST strike occurred in a 100-L cylindrical reactor similar to the one shown in Figure 1, with agitation provided by an air driven mixer. The flat-bottomed tank measured 14.75 inches in diameter and contained no baffles. The $66 \mathrm{~L}$ of waste corresponded to a liquid height of $\sim 23$ inches, given a working volume aspect ratio (i.e., height to diameter) of 1.4. We treated the salt solution with a single addition of $0.5 \mathrm{~g} / \mathrm{L}$ of TNX MST. After the MST addition, we agitated the slurry for 24 hours using an air driven mixer. Researchers removed and filtered samples after $0,1,2,3,8,12,24$ and 30 hours of mixing. Personnel did not monitor the air-flow rate but established a flow sufficient to observe a vortex $(\sim 1$ 3" deep) at the surface of the liquid. Personnel could not directly observe the mixing conditions due to the stainless steel construction of the tank. However, previously, the researchers performed a MST suspension test that indicated adequate suspension occurred under roughly similar mixing conditions. We filtered the samples through 0.45 micron disposable filters, diluted 100 fold (to reduce gamma dose rates) with $0.2 \mathrm{M}$ nitric acid, and sent them for analysis at least several hours later. We retained archival material of the caustic salt solutions for future use.

As discussed in the Results section below, the original ${ }^{14}$ analyses of the samples in 2001 yielded a considerable uncertainty in the plutonium analyses and indicated poorer than anticipated removal efficiency. To reduce the uncertainty, we subsequently analyzed the archived samples as described in the following paragraph. Personnel speculated that poor mixing conditions may have contributed in part to the lower than expected removal efficiency. Hence, personnel added baffles to the tank for subsequent demonstrations of the solvent extraction process and took additional care in examining the mixing conditions (see Tank 37H MST Demonstration).

The large variations between the data points may result in part from the large dilutions required to take the samples out of the high activity cells. Due to this difficulty in the actinide analyses, we desired to re-examine the success of the MST strike. From the original $37 \mathrm{H} / 44 \mathrm{~F}$ work, personnel stored the archived caustic samples in polyethylene bottles for 2 months. Researchers from the earlier demonstration stored samples of the archived feed material that had not been previously contacted with MST without filtering, while storing samples of the material previously exposed to MST contact after filtering to remove the solids. We used these samples for additional analyses. To avoid the 
limitations associated with the large dilutions, we treated the samples with AMP (ammonium molybdophosphate), a cesium removal resin. Personnel added $3 \mathrm{~mL}$ of each caustic solution to a bottle containing $6 \mathrm{~mL}$ of $5 \mathrm{M}$ nitric acid and $\sim 40 \mathrm{mg}$ of AMP resin. They then agitated each sample mixture thoroughly, and filtered the AMP resin using $0.45 \mathrm{~mm}$ Teflon ${ }^{\mathrm{TM}}$ filters. We submitted the acidified samples for analysis. Thus the main difference between the two sets of analyses - i.e., the earlier and current demonstrations - involved the use of AMP instead of dilution and the lack of filtering the samples before the acid dilution.

\section{Figure 1. The $100 \mathrm{~L}$ Reactor Used for the Tank 37H/44F MST Strike}

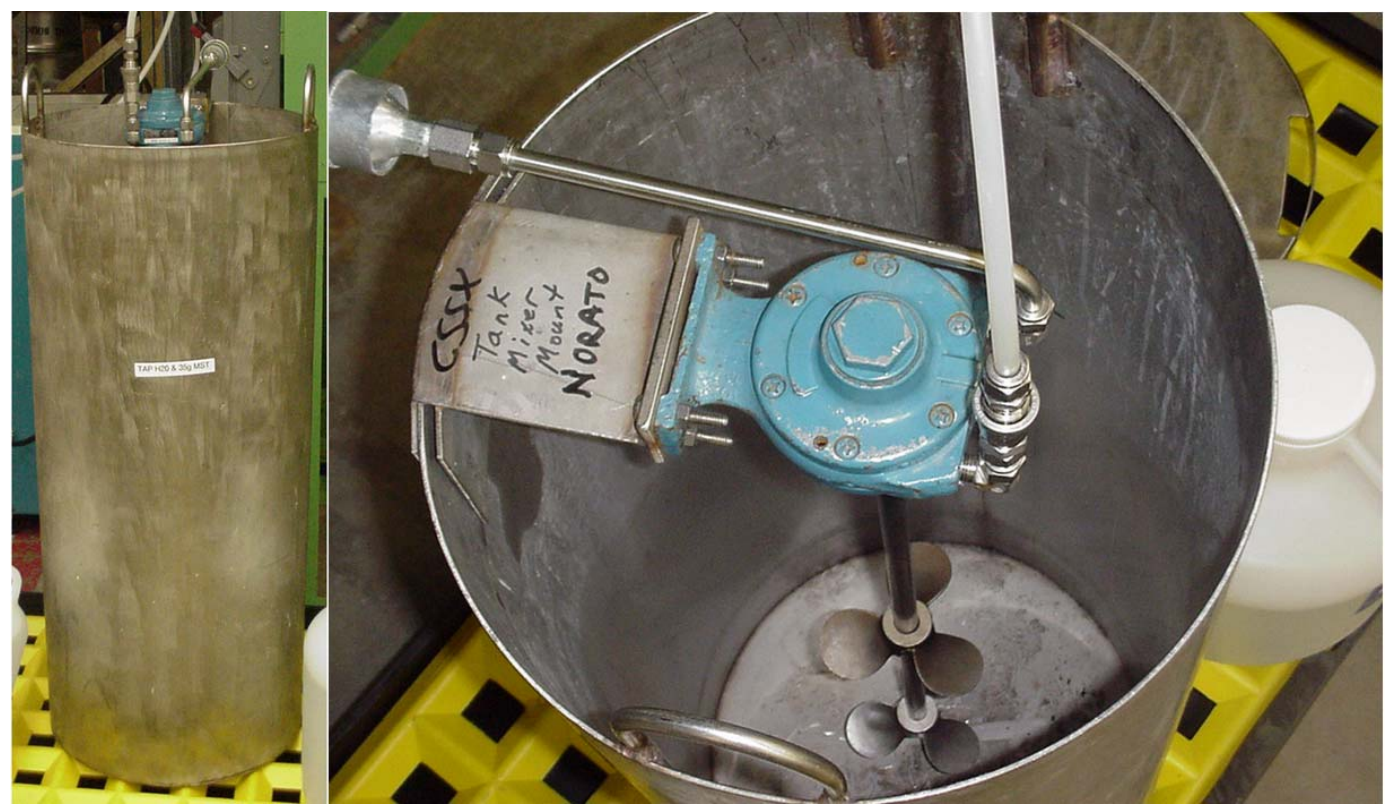

\subsection{Tank 37H MST Demonstration}

In preparation for a second solvent extraction demonstration, ${ }^{16}$ High Level Waste personnel filled a 38-L sampler with dissolved saltcake waste from Tank 37H in April 2002. Personnel collected the sample at the start of salt cake dissolution operations. After transporting the sample to SRTC, personnel placed the sample into a shielded facility for processing. Table 4 summarizes source information for the sample.

The sodium ion concentration of the as-received waste solution (density, $1.490 \mathrm{~g} / \mathrm{mL}$; $\sim 14 \mathrm{M} \mathrm{Na}^{+}$) exceeded the desired processing concentration of $5.6 \mathrm{M} \mathrm{Na}^{+}$. Personnel transferred a portion of the waste solution $(25.5 \mathrm{~L})$ to an empty tank and diluted it with 1.6 $\mathrm{M} \mathrm{NaOH}$ solution (45 L) simulating the planned operations for the Salt Waste 
WSRC-TR-2002-00355

Table 4. Origin of Tank 37H Waste

\begin{tabular}{|l|l|}
\hline Source & Tank $37 \mathrm{H}$ \\
\hline Date Sampled & $4 / 16 / 2002$ \\
\hline Identification Number & $\mathrm{HTK}-496$ \\
\hline Date received at SRTC & $4 / 17 / 02$ \\
\hline Approximate volume (L) & 37 \\
\hline Densitv (g/mL) & 1.490 \\
\hline $\mathbf{N a}^{+}$(molaritv) & $\sim 14$ \\
\hline
\end{tabular}

Processing Facility. After dilution, the final sodium ion concentration of $6.22 \mathrm{M}$ adequately approximated the $5.6 \mathrm{M}$ target. Table 5 lists the composition of the diluted solution. Researchers measured the solution density by weighing portions in $50-\mathrm{mL}$ volumetric flasks using a balance sensitive to $\pm 1 \mathrm{mg}$. We diluted unfiltered portions (1 $\mathrm{mL}$ ) in 99 grams of water or $0.2 \mathrm{M}$ nitric acid and sent them for routine analyses. We calculated the exact dilution factors from the density, weight of the nominal 1-mL sample, and weight of the water, assuming ideal mixing of the waste and water. Personnel measured the sodium ion concentration by ICP-ES. We determined the plutonium by PuTTa analysis, the strontium- 90 activity by beta scintillation, and the uranium and neptunium concentrations by ICP-MS. Appendix 2 contains all the ICP-MS results in the actinide range.

Table 5. Composition of the Tank 37H Waste*

\begin{tabular}{|c|c|c|c|}
\hline Component & Concentration(M) & Component & Activity $(\mathrm{dpm} / \mathrm{mL})$ \\
\hline $\mathrm{Na}^{+}$ & 6.22 & ${ }^{90} \mathrm{Sr}$ & $3.7 \mathrm{E}+06$ \\
\hline $\mathrm{K}^{+}$ & 0.039 & ${ }^{137} \mathrm{Cs}$ & $3.2 \times 10^{9}$ \\
\hline $\mathrm{Cs}^{+}$ & 0.00034 & $238 / 235 \mathrm{U}$ & $0.73 \mathrm{ppm}$ \\
\hline Free $\mathrm{OH}^{-}$ & 3.7 & ${ }^{237} \mathrm{~Np}$ & $<0.019 \mathrm{ppm}$ \\
\hline $\mathrm{NO}_{3}^{-}$ & 0.73 & $238 \mathrm{Pu}$ & $4.3 \mathrm{E}+03$ \\
\hline $\mathrm{NO}_{2}^{-}$ & 0.88 & $239 / 240 \mathrm{Pu}$ & $<4.7 \mathrm{E}+02$ \\
\hline $\mathrm{AlO}_{2}^{-}$ & 0.54 & & \\
\hline $\mathrm{SO}_{4}{ }^{2-}$ & $<0.006$ & & \\
\hline $\mathrm{CO}_{3}{ }^{2-}$ & $<0.02$ & $\mathrm{pH}$ & $>14$ \\
\hline $\mathrm{PO}_{4}{ }^{3-}$ & 0.02 & Density & $1.240 \mathrm{~g} / \mathrm{mL}$ \\
\hline $\mathrm{F}^{-}$ & $<0.012$ & & \\
\hline $\mathrm{Cl}^{-}$ & 0.009 & & \\
\hline $\mathrm{C}_{2} \mathrm{O}_{4}^{2-}$ & $<0.013$ & & \\
\hline $\mathrm{HCO}_{2}^{-}$ & $<0.025$ & & \\
\hline
\end{tabular}

* Table shows composition after dilution with $1.6 \mathrm{M} \mathrm{NaOH}$ to achieve $6.22 \mathrm{M} \mathrm{Na}^{+}$. 
For the MST treatment, we placed $70 \mathrm{~L}$ of Tank $37 \mathrm{H}$ salt solution into a $100-\mathrm{L}$ total volume cylindrical reactor with baffles (similar to Figure 1, but with $4,90^{\circ}$ spaced baffles). These conditions provided a working volume aspect ratio (i.e., height to diameter) of 1.5. The four baffles were spaced 90 degrees apart. Each baffle measured 1.5 inches in width, spaced 0.25 inches from the wall and 0.5 inches from the bottom of the tank. Again, we used an air-driven agitator to mix the slurry. While stirring the slurry fast enough to generate a vortex, personnel added a single MST strike of $0.4 \mathrm{~g} / \mathrm{L}$ (170.1 g of "TNX" batch MST slurry). Personnel collected dip samples of the supernate just before addition of MST and at 1, 2, 4, 8, 24, 26, 30, and 48 hours thereafter. We immediately filtered material from each sampling time using $0.45 \mathrm{~mm}$ nylon syringe filters, diluted the filtered samples with $5 \mathrm{M}$ nitric acid and removed the samples from the cells for analysis. Although we did not allow the acidified samples to sit for several hours, the low levels of plutonium present in the solution should not have presented the slow plutonium dissolution problem we saw in the Bounding Waste experiments. ${ }^{12}$

\subsection{Hydraulically Scaled Demonstrations}

The Hydraulically Scaled Demonstrations examined the efficacy of MST or permanganate in actinide and strontium removal using conditions similar to those planned for the Actinide Removal Process (ARP). Figure 2 shows a simplified drawing

Figure 2. The Actinide Removal Process Reactor (simplified view)

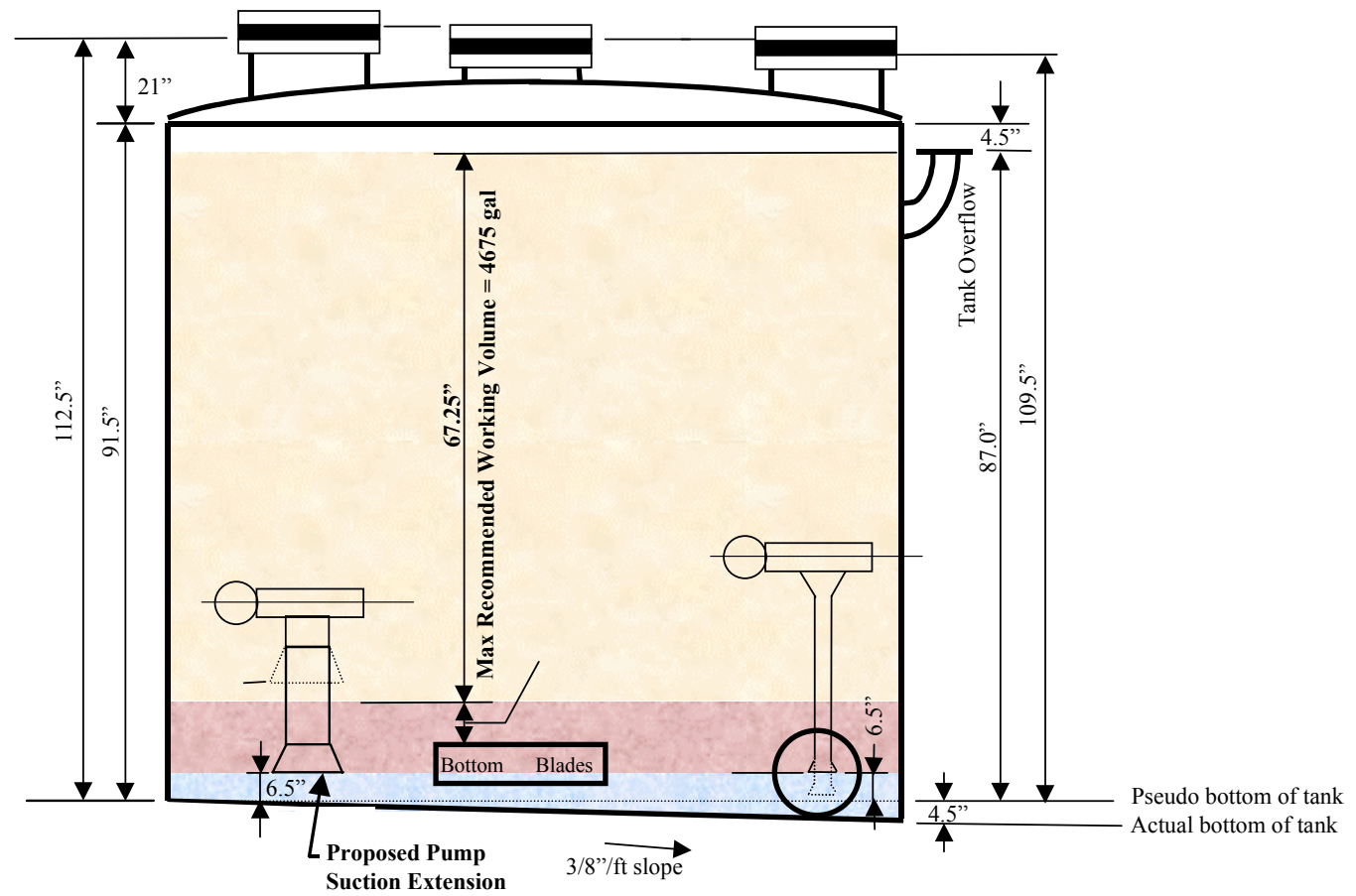


of the full size ARP reactor, supplied by the Satish (Sam) Shah. Personnel fabricated a $30 \mathrm{~L}$ working volume reactor (see Figure 3) that roughly emulates the conditions of the full scale unit, at a smaller size, and without the internal plumbing of the full scale unit. We designed the equipment and selected the agitator to provide equivalent mixing conditions (i.e., tip speeds and geometrical similarity) between the two reactors. The 30$\mathrm{L}$ reactor has the same sloping bottom as in the real tank. Appendix 3 provides the engineering calculations for the hydraulics.

The actual ARP vessel allows for a 4675 gal working volume. The mixing energy of the ARP agitator ensures turbulent conditions and, hence, will likely resemble that used in the full-scale Salt Waste Processing Facility with an anticipated working volume of 89,900 gal for the MST process. ${ }^{17}$ For permanganate, the anticipated working volume for the SWPF equals 69,000 gal. ${ }^{18}$ Permanganate treatment requires a smaller reaction vessel due to faster kinetics. Table 6 provides the approximate scaling factors, based on volume, comparing laboratory work with actual facilities.

These demonstrations represent a 300 to 700 scale increase from prior laboratory studies. Another factor of 250-590 separates these experiments from the ARP. Hence, the experiments approximately halved the scaling to the ARP. (The full-scale SWPF will increase working volumes another factor of 14-19.)

Table 6. Approximate Scaling Factors for Experiments and Actual Facilities

\begin{tabular}{|c|c|c|c|}
\hline & \multirow[b]{2}{*}{ Volume } & \multicolumn{2}{|c|}{ Scaling Factor } \\
\hline & & MST Process & $\begin{array}{c}\text { Permanganate } \\
\text { Process }\end{array}$ \\
\hline Typical lab experiments & $0.1 \mathrm{~L}$ & 1 & 1 \\
\hline $\begin{array}{l}\text { Hydraulically scaled } \\
\text { demonstrations }\end{array}$ & $30 \mathrm{~L}$ & 300 & 300 \\
\hline $\begin{array}{l}\text { Solvent extraction } \\
\text { demonstrations }\end{array}$ & $\sim 70 \mathrm{~L}$ & 700 & 700 \\
\hline $\begin{array}{l}\text { Actinide Removal Process } \\
\text { (Building 512-S) }\end{array}$ & $4676 \mathrm{gal}$ & 177,000 & 177,000 \\
\hline $\begin{array}{l}\text { Salt Waste Processing Facility } \\
\text { (full scale) }\end{array}$ & $\begin{array}{l}69,000 \text { gal } \\
89,900 \text { gal }\end{array}$ & $\begin{array}{c}\text { NA } \\
\sim 3,400,000 \\
\end{array}$ & $\begin{array}{c}\sim 2,610,000 \\
\text { NA }\end{array}$ \\
\hline
\end{tabular}

$$
\text { NA }=\text { Not Applicable }
$$

We conducted a test to determine if the calculated mixing conditions for the hydraulically scaled demonstration would suspend MST. Personnel added $30 \mathrm{~L}$ of water, and $0.4 \mathrm{~g} / \mathrm{L}$ of TNX batch MST while agitating at 300 RPM. After one minute of stirring, personnel used a slurry pipette to pull a slurry sample at one inch and six inches of depth (the solution depth was 8.4"). They then increased the stirring rate to 400 RPM, and obtained 
samples at one and six inches. Finally, they operated the stirrer at 500 RPM and collected another set of one and six inch samples. We sent each of these samples for a suspended solids analysis. Table 7 shows the results.

Figure 3. The 30 L Reactor with Overhead Stirrer

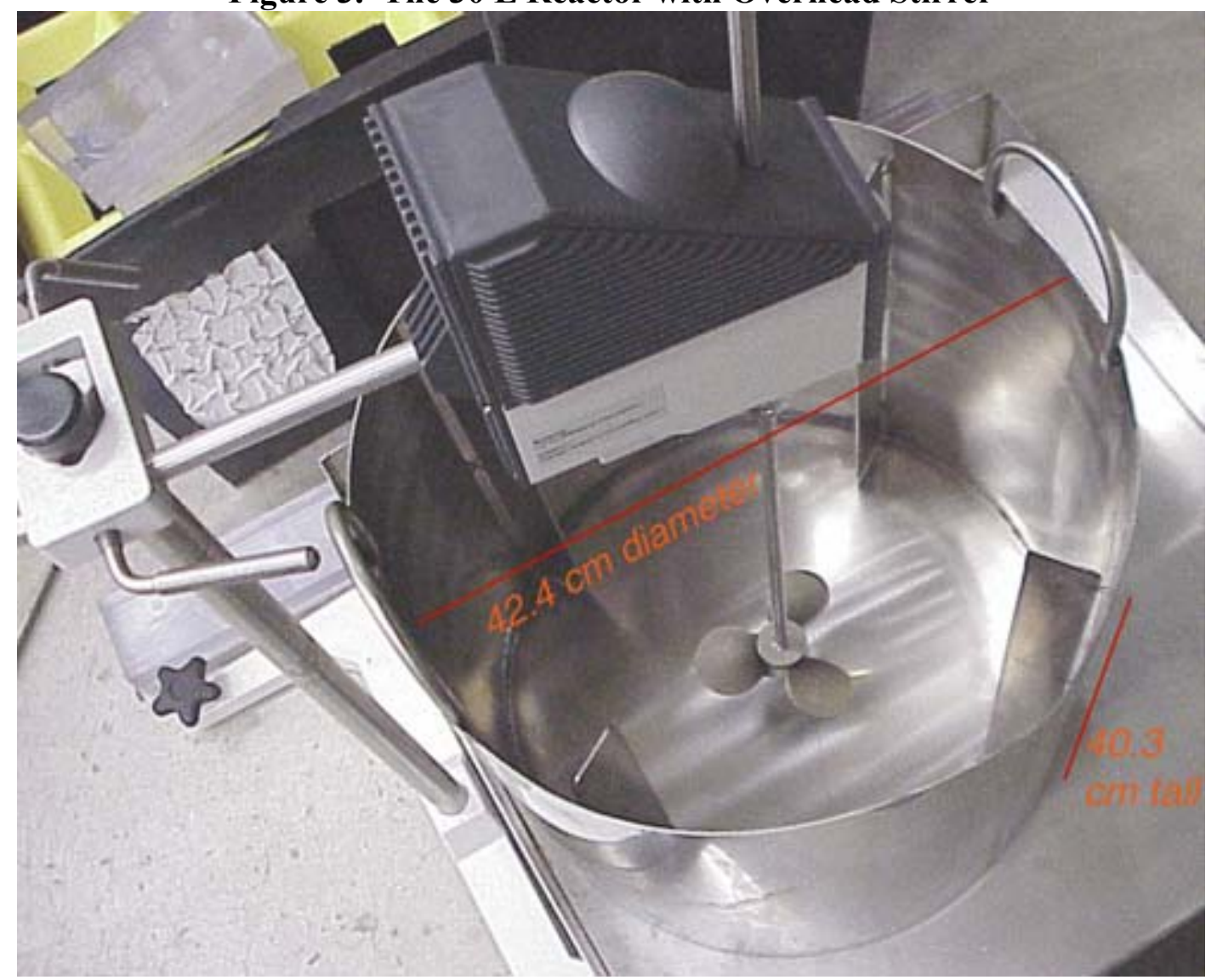

Table 7. Suspended Solids Analysis for the Hydraulically Scaled Reactor

\begin{tabular}{|c|c|c|}
\hline Stirring Rate & Depth from top (inches) & Suspended Solids (\%) \\
\hline 300 & 1 & 0.083 \\
\hline 300 & 6 & $0.285 *$ \\
\hline 400 & 1 & 0.122 \\
\hline 400 & 6 & 0.073 \\
\hline 500 & 1 & 0.073 \\
\hline 500 & 6 & 0.130 \\
\hline \multicolumn{2}{|c|}{$*$ ADS suspects that this result is biased high } \\
\hline
\end{tabular}

A Q-test of the data shows that we can discard the 0.285 data point as an outlier. If we statistically examine the remaining data points, we find that the data shows no real dependence on either mixing speed or sampling depth. While the samples show higher than expected solids content, the lack of a pattern would at the least indicate that the 
material is not residing largely near the bottom of the vessel. Furthermore, the test used water, which is harder to suspend particulates in, compared to the denser, viscous salt solutions present in the process.

For the demonstrations, we used $45 \mathrm{~L}$ of Tank $37 \mathrm{H} / 44 \mathrm{~F}$ salt solution from prior testing that included a MST strike to remove strontium and actinides followed by processing through a solvent extraction process to remove the cesium. We filled the reactor with $30 \mathrm{~L}$ of solution and saved the rest for future use. For these tests, we added ${ }^{85} \mathrm{Sr}$, ${ }^{239} / 240 \mathrm{Pu},{ }^{237} \mathrm{~Np},{ }^{238} \mathrm{U}$, non-radioactive cesium and non-radioactive strontium in the amounts listed in Table 8 . We added the actinides and ${ }^{85} \mathrm{Sr}$ as a pre-prepared solution in the following manner. Technicians added the uranium, neptunium, plutonium and ${ }^{85} \mathrm{Sr}$ solutions to $5.0 \mathrm{~mL}$ of $0.01 \mathrm{M}$ nitric acid. To this stirring acid solution, researchers slowly added small quantities of sodium carbonate until the solution registered alkaline as determined using $\mathrm{pH}$ strips. Addition of the sodium carbonate was done to adjust the actinide/strontium solution to a more caustic level which lessened the chances of a sudden precipitation of the strontium and actinides when we added the solution to the reactor. We detected no visible evidence of solids formation, and allowed the mixture to stir for $\sim 5$ minutes before slowly adding to the agitated, 30-L reactor.

\section{Table 8. Type and Amount of Added Spike in the Hydraulically Scaled Demonstration}

\begin{tabular}{|l|c|}
\hline \multicolumn{1}{|c|}{ Added Species } & Target Concentration \\
\hline $\mathrm{Cs}\left(\mathrm{NO}_{3}\right)$ & $17.9 \mathrm{mg} / \mathrm{L}$ \\
\hline $\mathrm{Sr}\left(\mathrm{NO}_{3}\right)_{2}$ & $0.15 \mathrm{mg} / \mathrm{L}$ \\
\hline${ }^{85} \mathrm{SrCl}_{2} / \mathrm{HCl}$ solution & $18.4 \mathrm{nCi} / \mathrm{g}$ \\
\hline${ }^{238} \mathrm{UO}_{2}\left(\mathrm{NO}_{3}\right)_{2} \cdot 6 \mathrm{H}_{2} \mathrm{O}$ & $10 \mathrm{mg} / \mathrm{L}$ \\
\hline${ }^{237} \mathrm{~Np}(\mathrm{~V}) / \mathrm{HNO}_{3}$ solution & $0.231 \mathrm{nCi} / \mathrm{g}$ \\
\hline${ }^{239 / 240} \mathrm{Pu}(\mathrm{IV}) / \mathrm{HNO}_{3}$ solution & $11.5 \mathrm{nCi} / \mathrm{g}$ \\
\hline
\end{tabular}

After the additions, we equilibrated the $32 \mathrm{~L}$ of solution over a period of 3 weeks. Technicians periodically collected samples and filtered them during this time to determine if the strontium and actinide concentrations had equilibrated. See Table 9 for the radioisotope concentrations during the equilibration period and Figures 4 and 5 for the graphical presentation of the data. The strontium, neptunium and uranium concentrations all reasonably equilibrated. The plutonium showed a distinct drop in activity midway through the equilibration period. We attribute this drop to changes in the plutonium chemistry caused by evaporative losses over the period, possibly in combination with $\mathrm{CO}_{2}$ uptake during that time. We judged the solution as equilibrated sufficiently after three weeks and proceeded with the demonstration. At this time, we removed a 2-L portion for use in the D. T. Hobbs' test (see below). 
Table 9. Radioisotope Concentrations during the Equilibration Period

\begin{tabular}{|c|c|c|c|c|}
\hline Date & Total $\mathrm{Pu}(\mathrm{nCi} / \mathrm{g})$ & ${ }^{85} \mathrm{Sr}(\mathrm{nCi} / \mathrm{g})$ & ${ }^{237} \mathrm{~Np}(\mathrm{mg} / \mathrm{L})$ & Total U $(\mathrm{mg} / \mathrm{L})$ \\
\hline $6 / 24 / 02$ & 12.4 & 14.8 & 0.323 & 11.3 \\
\hline $7 / 1 / 02$ & 14.7 & 17.5 & 0.398 & 13.2 \\
\hline $7 / 8 / 02$ & 12.6 & 21.3 & 0.453 & 13.8 \\
\hline $7 / 15 / 02$ & 0.21 & 12.2 & 0.320 & 12.5 \\
\hline
\end{tabular}

Figure 4. Equilibrium Concentrations of Plutonium and Strontium

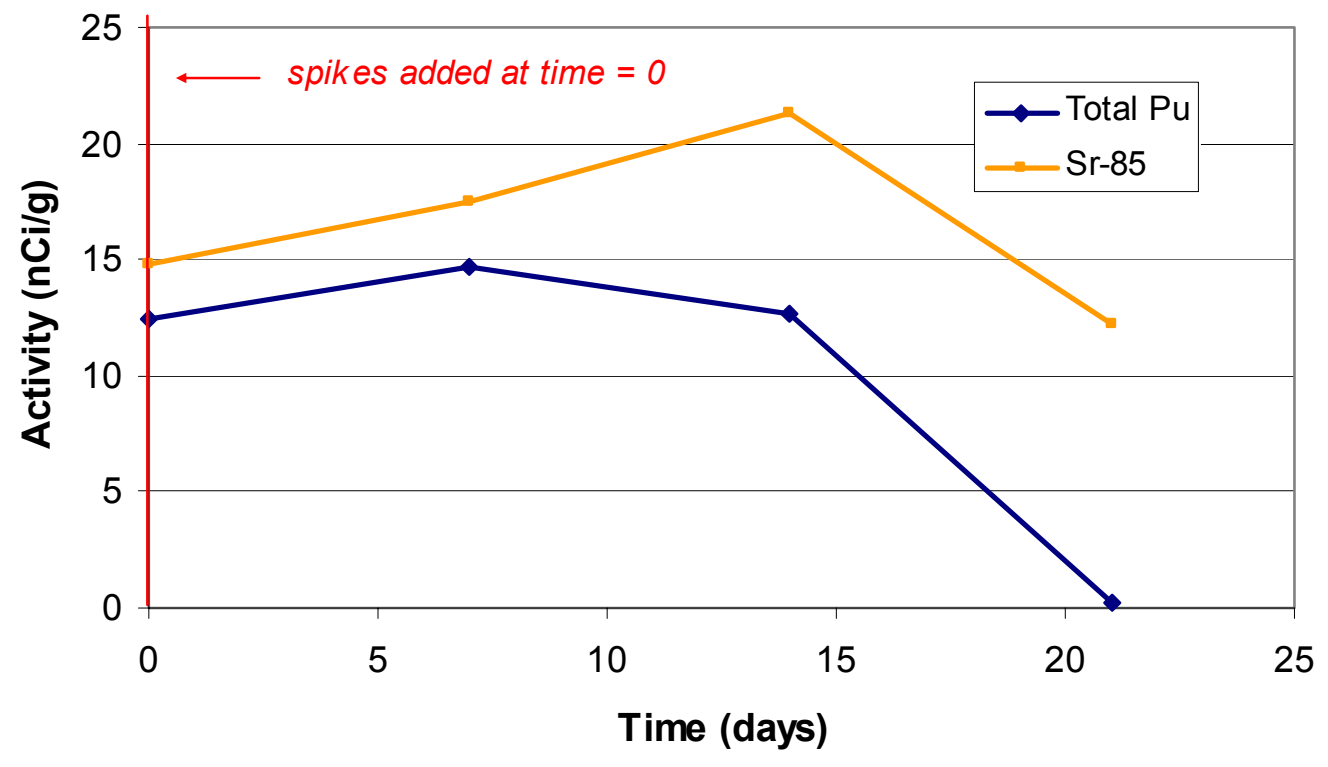

Figure 5. Equilibrium Concentrations of Neptunium and Uranium

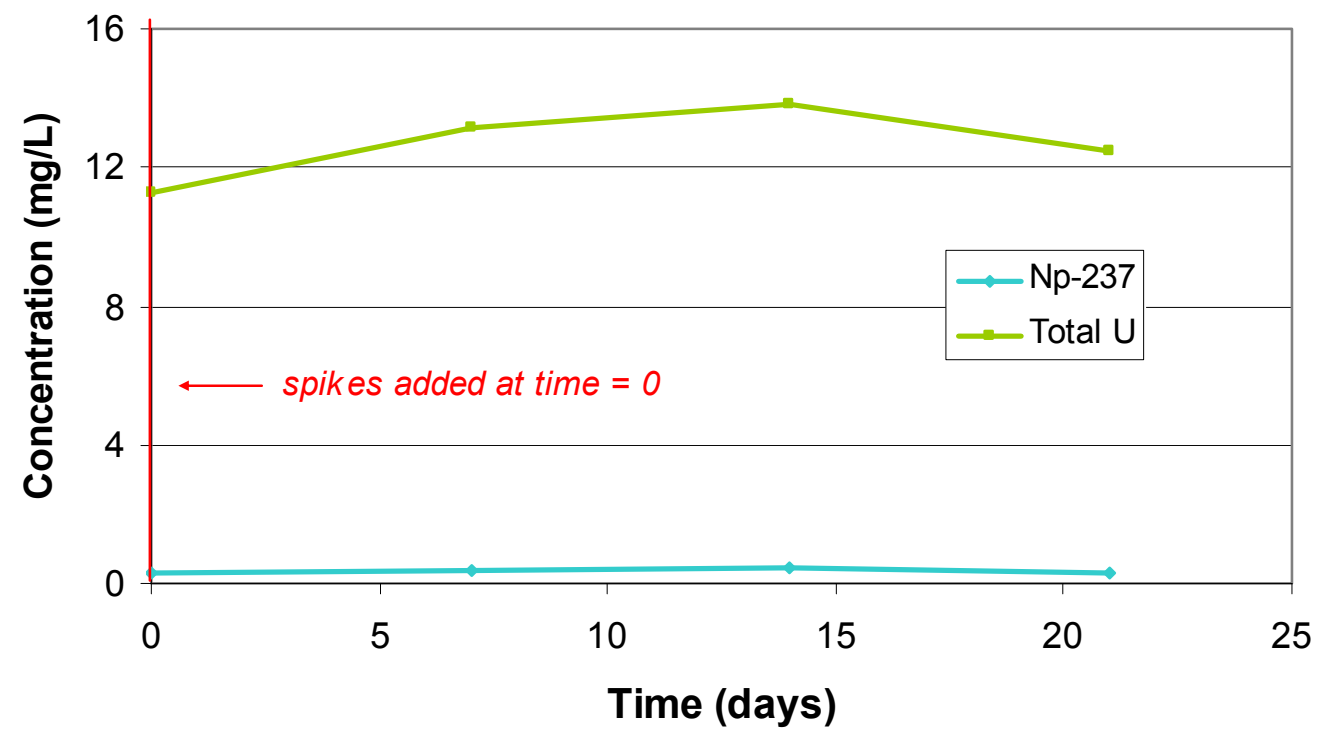


WSRC-TR-2002-00355

We added nonradioactive cesium nitrate $(840 \mathrm{mg})$ to serve as a control. Ten minutes after the addition of the cesium compound, technicians collected a $125 \mathrm{~mL}$ control sample and placed into a separate bottle. Then, while stirring, researchers added a single MST strike of $73.8 \mathrm{~g}$ (to achieve $0.4 \mathrm{~g} / \mathrm{L}$ ) of (TNX batch) MST in the bulk. Researchers pulled samples from the reactor and from the control bottle immediately after addition of MST to the reactor and at 2, 4, 12, 18, 24, and 30 hours thereafter. Later, they filtered portions of each sample, acidified for at least several hours and sent samples for analysis for plutonium by PuTTa, strontium and radiocesium by gamma spectroscopy, neptunium and uranium by RADICP-MS and cold cesium by ICP-MS.

As a scaling and mixing effects comparison, a series of experiments were carried on in parallel by D. T. Hobbs. While it is beyond the scope of this document to present all the experimental details, these experiments used $125 \mathrm{~mL}$ poly bottles agitated through the use of a shaker bath. The salt solutions used came from our equilibrated salt solution. Hobbs ran DF determinations over a 24 hour period using $100 \mathrm{~mL}$ of this solution with $0.4 \mathrm{~g} / \mathrm{L}$ of TNX batch MST. Hobbs pulled samples at time $=0$ (before MST addition) and 24 hours. He filtered portions of each sample, acidified them and sent for them analysis for plutonium by PuTTa, strontium and radiocesium by gamma spectroscopy, neptunium and uranium by RADICP-MS and nonradioactive cesium by ICP-MS. In general, the results of Hobbs' work agreed well with our Large Scale Demonstrations and are presented in sections below.

After completing the MST demonstration, we emptied the reactor by pumping out the contents, and in the process, filtered the liquid using a $0.45 \mu \mathrm{m}$ nylon cartridge filter to remove MST solids. We added water to the filtrate to return it to its original volume, thus replacing evaporative losses. We then added $30 \mathrm{~L}$ of this salt solution to the reactor. Afterwords, SRTC performed an analogous demonstration using sodium permanganate $\left(\mathrm{NaMnO}_{4}\right)$, strontium nitrate $\left(\mathrm{Sr}\left(\mathrm{NO}_{3}\right)_{2}\right)$ and hydrogen peroxide $\left(\mathrm{H}_{2} \mathrm{O}_{2}\right)$. We added the radioisotopes in the same amounts and manner as the first hydraulically scaled demonstration, and allowed the solution to equilibrate (see Table 10 and Figures 6 and 7).

Table 10. Radioisotope Concentrations during the Equilibration Period

\begin{tabular}{|c|c|c|c|c|}
\hline Date & Total $\mathrm{Pu}(\mathrm{nCi} / \mathrm{g})$ & ${ }^{85} \mathrm{Sr}(\mathrm{nCi} / \mathrm{g})$ & ${ }^{237} \mathrm{~Np}(\mathrm{mg} / \mathrm{L})$ & Total U $(\mathrm{mg} / \mathrm{L})$ \\
\hline $7 / 30 / 02$ & 3.55 & 7.97 & 0.466 & 21.5 \\
\hline $8 / 6 / 02$ & 2.94 & 7.86 & 0.380 & 17.2 \\
\hline $8 / 15 / 02$ & 3.90 & 8.12 & 0.312 & 16.2 \\
\hline $9 / 11 / 02$ & 2.56 & 7.56 & 0.415 & 20.2 \\
\hline $9 / 16 / 02$ & $1.05^{*}$ & $6.44^{*}$ & $0.430^{*}$ & $20.9^{*}$ \\
\hline
\end{tabular}

* This value is the simple average of the two data points taken at the same time 
The strontium, neptunium and uranium concentrations showed stable behavior during the equilibration period. On 9/11/02, we added $2.5 \mathrm{~L}$ (or 8 vol \%) water to replace evaporative losses. Analysis of the subsequent samples showed the actinide and strontium concentrations decreased following the water addition (Figures 6 and 7).

Although the magnitude of the drop did not precisely equal that expected from dilution, we judged the differences within the analytical uncertainty. The exact permanganate recipe used for the second hydraulically scaled demonstration came from previous work

\section{Figure 6. Equilibrium Concentrations of Plutonium and Strontium}

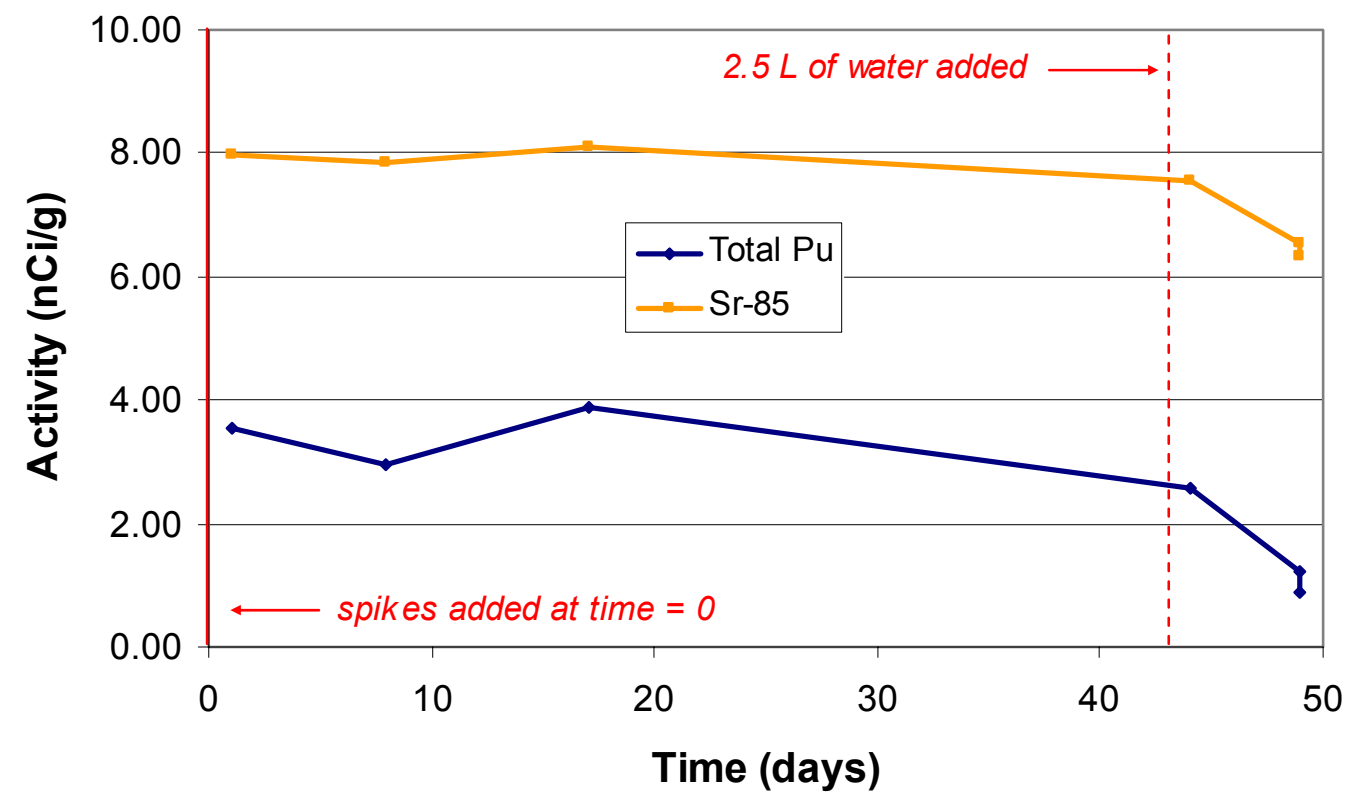

Figure 7. Equilibrium Concentrations of Neptunium and Uranium

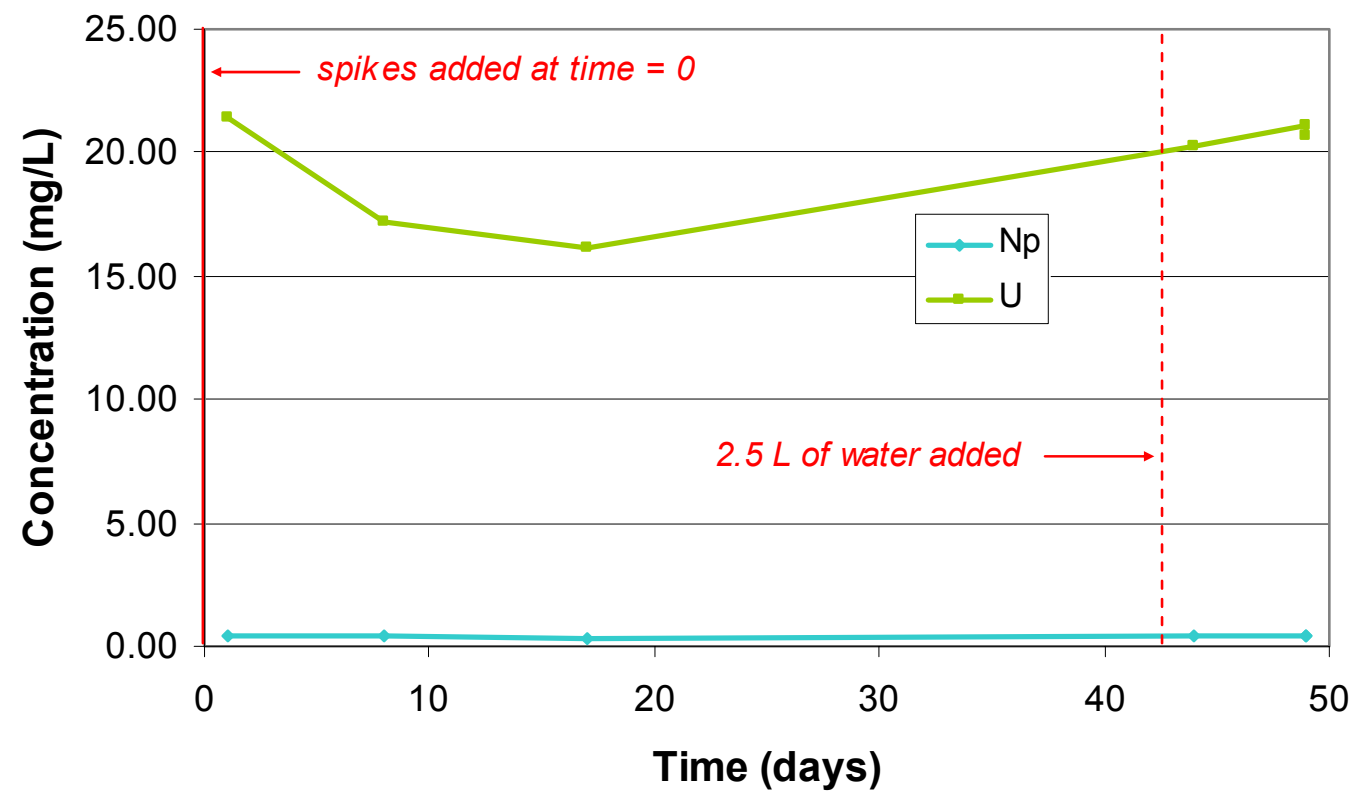


by Hobbs, et al. ${ }^{19}$ Using this recipe, researchers first made three different salt solutions; a $1.2 \mathrm{~L}$ of a $0.8 \mathrm{M} \mathrm{NaMnO}_{4}$ solution, $0.125 \mathrm{~L}$ of a $3.56 \mathrm{M} \mathrm{Sr}\left(\mathrm{NO}_{3}\right)_{2}$ solution, and a $0.605 \mathrm{~L}$ solution of $6.4 \mathrm{wt} \% \mathrm{H}_{2} \mathrm{O}_{2}$. Before the addition of these solutions, researchers pulled a $125 \mathrm{~mL}$ sample and placed it in the control bottle. Personnel sampled both the reactor and control bottle before proceeding.

Researchers first added the $\operatorname{Sr}\left(\mathrm{NO}_{3}\right)_{2}$ solution to the stirring reactor, immediately generating a creamy white suspension. (The target concentration of strontium, assuming equal distribution, equaled $0.01 \mathrm{M}$.) After allowing the contents to stir for five minutes, we added the $\mathrm{NaMnO}_{4}$ solution, which gave a smooth purple suspension/solution (with a target concentration of $0.03 \mathrm{M}$ permanganate, assuming equal distribution). The researchers waited for five minutes, after which point we slowly (over a period of $\sim 30$ minutes) added the $\mathrm{H}_{2} \mathrm{O}_{2}$ solution (to a target concentration of $0.045 \mathrm{M}$ peroxide, assuming equal distribution). Over the period of the $\mathrm{H}_{2} \mathrm{O}_{2}$ addition, the solution/suspension color slowly changed from deep purple to dark green, and finally to brown. At the same time, addition of the $\mathrm{H}_{2} \mathrm{O}_{2}$ caused the generation of an effervescent gas (e.g., oxygen from the $\mathrm{H}_{2} \mathrm{O}_{2}$ decomposition). After complete addition of the $\mathrm{H}_{2} \mathrm{O}_{2}$, researchers pulled samples from the reactor and from the control bottle at 2, 4, 12, 18, 24, and 30 hours thereafter. They filtered portions of each sample, acidified and sent for analysis for plutonium (by PuTTa), strontium and cesium (by gamma spectroscopy), and neptunium and uranium (RADICP-MS).

\subsection{Results of Investigations}

\subsection{Tank 37H/44F MST Demonstration}

For the Tank $37 \mathrm{H} / 44 \mathrm{~F}$ demonstration in 2001, researchers analyzed for plutonium, strontium, neptunium, and uranium. In 2002, researchers decided to re-analyze the plutonium and strontium results.

After the initial set of analyses, the researchers took samples and stored them as archival material. They stored samples of the feed material - prior to MST treatment - without filtering, and stored MST treated samples after filtering through $0.45 \mathrm{~mm}$ Teflon ${ }^{\mathrm{TM}}$ filters.

\subsubsection{Plutonium Results}

Researchers in $2001^{14}$ analyzed the filtered supernates for total plutonium (-238, 239/240) activity. Table 11 reports the data while Figure 8 shows the results in graphical form. Error bars are added for comparison. Mass data for the plutonium is presented in Appendix 4. 
WSRC-TR-2002-00355

Table 11. Total Plutonium Concentrations in the $37 \mathrm{H} / 44 \mathrm{~F}$ Filtrate

\begin{tabular}{|c|c|c|c|}
\hline Time (hours) & 238Pu (nCi/g) & $239 / 240 \mathrm{Pu}(\mathrm{nCi} / \mathrm{g})$ & Total $\mathrm{Pu}(\mathrm{nCi} / \mathrm{g})$ \\
\hline 0 (just before MST addn) & 0.33 & 0.055 & 0.39 \\
\hline 1 & 0.25 & 0.015 & 0.26 \\
\hline 2 & 0.26 & 0.034 & 0.30 \\
\hline 3 & 0.14 & 0.015 & 0.15 \\
\hline 8 & 0.18 & 0.017 & 0.20 \\
\hline 12 & 0.15 & 0.017 & 0.16 \\
\hline 24 & 0.13 & 0.011 & 0.14 \\
\hline 30 & 0.22 & 0.028 & 0.24 \\
\hline
\end{tabular}

Based on the 24 hour data, the MST addition yielded a total plutonium DF of 2.8. The 30 hour data may reflect sample contamination, but without later samples, this remains conjecture. The large variations between the data may also reflect, in part, analytical variance due to the large dilutions required to remove the samples from the cells (i.e., due to high radiocesium activity). Due to this difficulty in the actinide analyses, we

Figure 8. Total Plutonium Activity from 2001 Analysis for the 37H/44F Filtrate

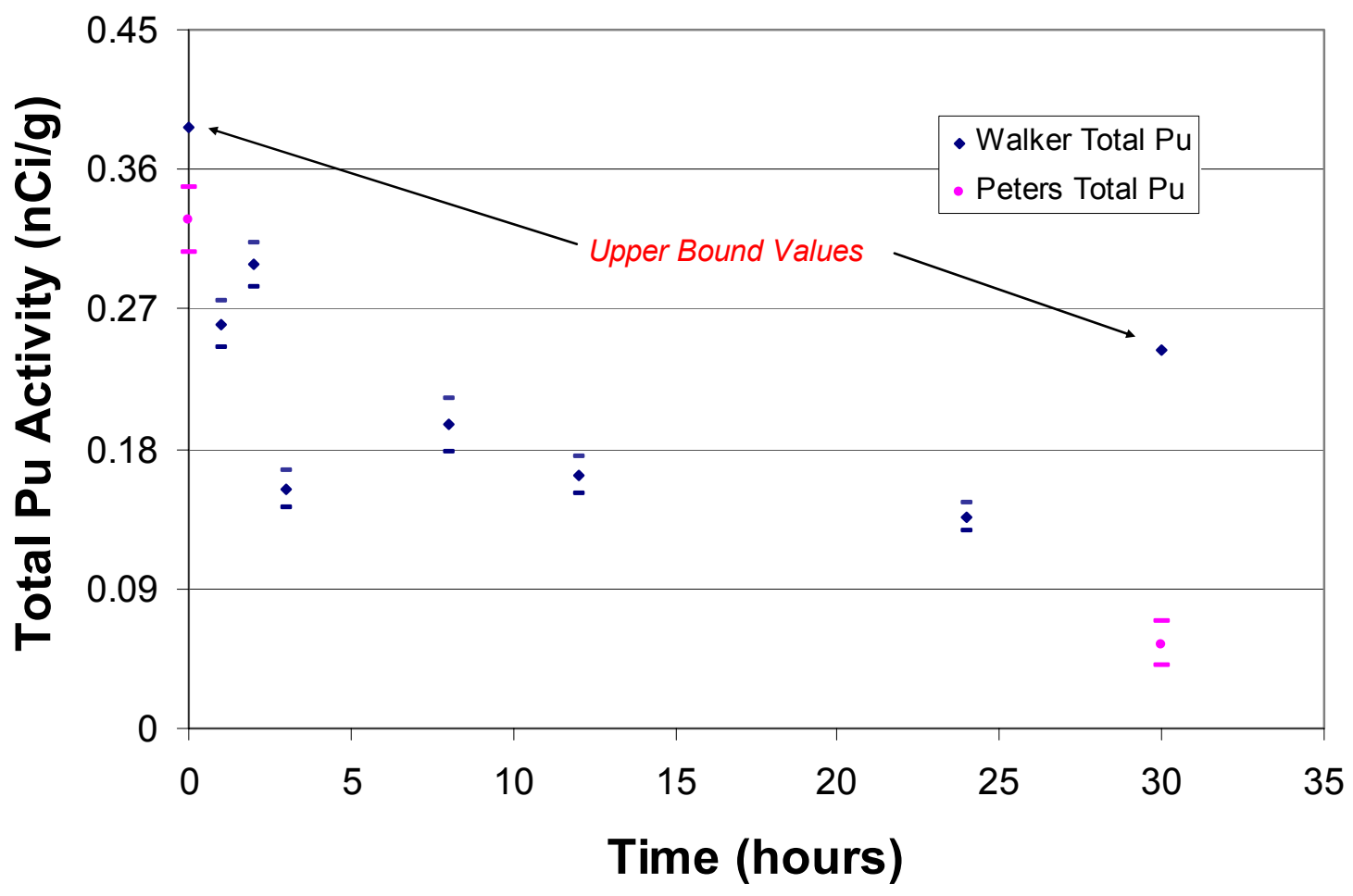


WSRC-TR-2002-00355

performed additional analyses on archived samples of the waste from before and after MST addition. To avoid the limitations associated with the large dilutions, we treated the samples with ammonium molybdophosphate resin (AMP) to remove cesium. Literature data shows negligible affinity of the resin for actinides and researchers are of the opinion that strontium is not sorbed either. ${ }^{20}$ We combined $3 \mathrm{~mL}$ of each caustic solution with 6 $\mathrm{mL}$ of $5 \mathrm{M}$ nitric acid and $\sim 40 \mathrm{mg}$ of AMP resin. Technicians agitated each sample thoroughly by shaking the sample bottles for about one minute, and then removed the AMP resin using $0.45 \mathrm{~mm}$ Teflon ${ }^{\mathrm{TM}}$ syringe filters. We submitted the acidified samples for plutonium analysis with results shown in Table 12. Figure 8 shows the graphical results.

Table 12. Plutonium Concentrations (2002) of 37H/44F Solution After AMP Treatment of the Solution

\begin{tabular}{|c|c|c|c|}
\hline Sample & $238 \mathrm{Pu}(\mathrm{nCi} / \mathrm{g})$ & $239 / 240 \mathrm{Pu}(\mathrm{nCi} / \mathrm{g})$ & Total $\mathrm{Pu}(\mathrm{nCi} / \mathrm{g})$ \\
\hline Before MST & 0.304 & 0.0236 & 0.328 \\
\hline After MST & 0.0491 & 0.00535 & 0.0544 \\
\hline
\end{tabular}

Comparison of the more recent plutonium results indicates a DF of 6.0 with a comparable initial concentration of plutonium. In fact, if one compares the relevant data points, it appears that there is an offset between the two data sets of $\sim 0.09 \mathrm{nCi} / \mathrm{g}$. The lower concentrations in the new analyses may be due to small amounts of precipitation occurring in the caustic solution during prolonged storage.

\subsubsection{Strontium Results}

In 2001, researchers analyzed the filtered supernates for strontium-90 activity. Table 13 reports the data while Figure 9 shows the information in graphical form.

Table 13. Strontium-90 Activity (2001) of the 37H/44F Solution in the Filtrate

\begin{tabular}{|c|c|}
\hline Time (hours) & $90 \mathrm{Sr}(\mathrm{nCi} / \mathrm{g})$ \\
\hline 0 (before MST addition) & 28.4 \\
\hline 1 & 5.53 \\
\hline 2 & 20.3 \\
\hline 3 & $<2.93$ \\
\hline 8 & 8.57 \\
\hline 12 & 3.25 \\
\hline 24 & 5.64 \\
\hline 30 & 6.81 \\
\hline
\end{tabular}


Based on the 24 hour data, MST treatment yielded a strontium DF of 5.0. The data at 2 hours presumably reflects contamination of the sample in the cells since the offset from the other data greatly exceeds the expected analytical variance.

We analyzed the 2001 archival samples for stronium-90 using the same AMP-treated sample material previously discussed. Table 14 contains the results. The graphical results are in Figure 9.

Figure 9. Strontium-90 Activity from 2001 Analysis of the 37H/44F Filtrate

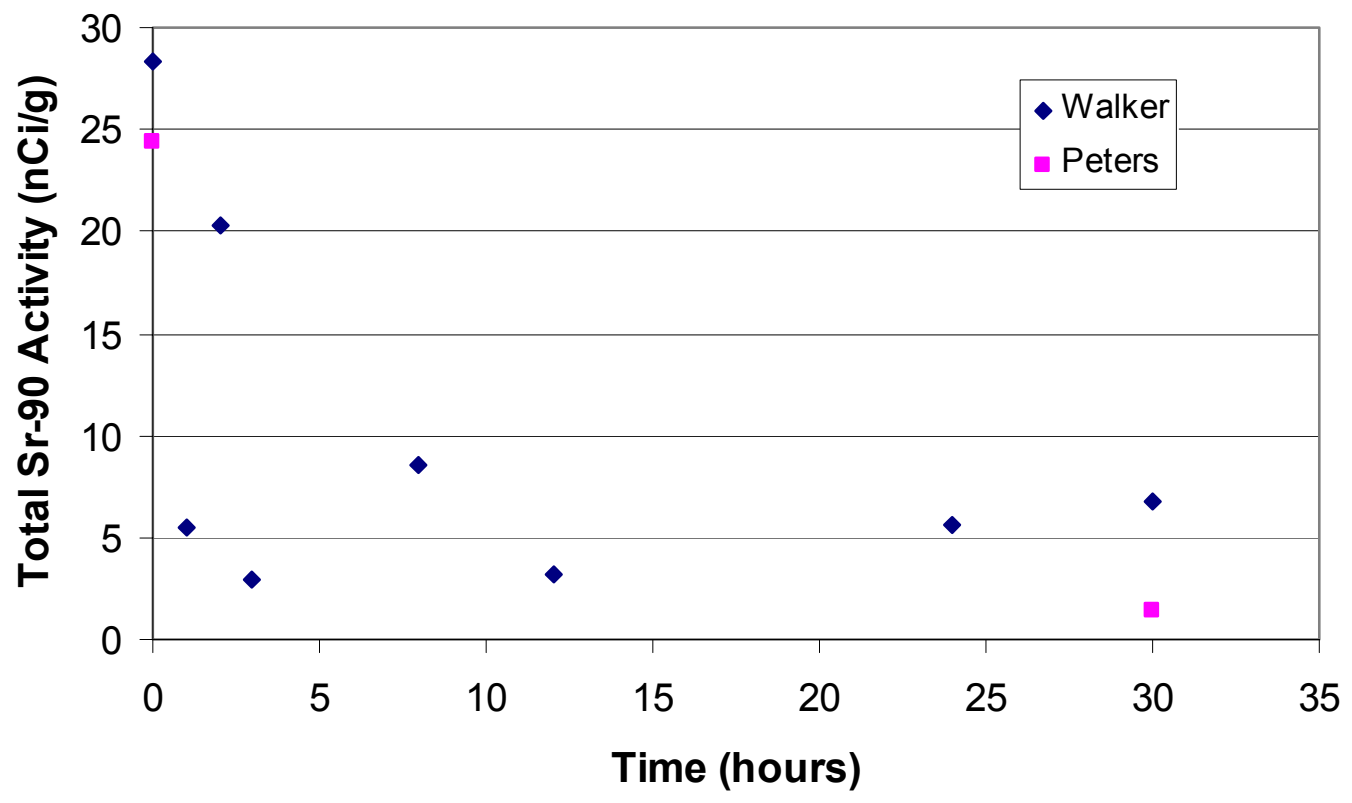

Table 14. Strontium Concentrations (2002) after AMP Treatment of the $37 \mathrm{H} / 44 \mathrm{~F}$ Solution

\begin{tabular}{|c|c|}
\hline Sample & ${ }^{90} \mathrm{Sr}(\mathrm{nCi} / \mathrm{g})$ \\
\hline Before MST & 24.4 \\
\hline After MST & 1.36 \\
\hline
\end{tabular}

Comparison of the strontium results indicates a DF of 17.9 with a comparable initial strontium concentration. If one compares the relevant data points, it appears that there is an offset between the two data sets of $\sim 4 \mathrm{nCi} / \mathrm{g}$. The lower concentrations in the new analyses may be due to small amounts of precipitation occurring in the caustic solution over time. 
WSRC-TR-2002-00355

\subsection{Tank 37H MST Demonstration}

\subsubsection{Plutonium Results}

Researchers analyzed the filtered supernates taken from the reactor for total plutonium $(-238,-239 / 240)$ activity. In an attempt to reduce the dilution required to remove the samples from the cells (thus increasing the analytical accuracy), we used AMP to strip radiocesium from the sample solutions. However, several attempts resulted in insufficient dose reduction, forcing us to use dilution. Table 15 reports the data.

Table 15. Total Plutonium Concentrations in the Tank $37 \mathrm{H}$ Filtrate

\begin{tabular}{|c|c|c|c|}
\hline Time (hours) & 238 $\mathrm{Pu}(\mathrm{nCi} / \mathrm{g})$ & $239 / 240 \mathrm{Pu}(\mathrm{nCi} / \mathrm{g})$ & Activity $\%$ 238 $\mathrm{Pu}$ \\
\hline $\begin{array}{c}0 \text { (just before MST } \\
\text { addition) }\end{array}$ & 1.57 & $<0.172$ & $>90.1$ \\
\hline 1 & 0.904 & $<0.0549$ & $>94.3$ \\
\hline 2 & 0.888 & $<0.0944$ & $>90.4$ \\
\hline 4 & 5.84 & 0.840 & 87.4 \\
\hline 8 & 1.06 & $<0.118$ & $>90.0$ \\
\hline 24 & 0.533 & $<0.0497$ & $>91.5$ \\
\hline 26 & 1.45 & 0.148 & 90.7 \\
\hline 30 & 2.37 & 0.180 & 92.9 \\
\hline 48 & 0.958 & 1.69 & 36.2 \\
\hline
\end{tabular}

The tabular data shows a wide variation in the plutonium results, and more importantly, the isotopic distribution. The data clearly shows random contamination from the cells. This is demonstrated by the wide swings in isotopic distribution. To evaluate the performance of MST, we restrict the analysis to that subset of the data that reports a ${ }^{238} \mathrm{Pu}$ isotopic activity of $90-92 \%$ and less than detectable $239 / 240 \mathrm{Pu}$ (see Table 15). The data at $0,2,8$, and 24 meet both criteria. Figure 10 displays this subset of "qualified" data. Based on this (i.e., the 0 and 24 hour points), the treatment yielded an approximate DF of 2.9. 
WSRC-TR-2002-00355

Figure 10. Plutonium-238 Activity in the Tank 37H Filtrate (absent suspected contaminated data)

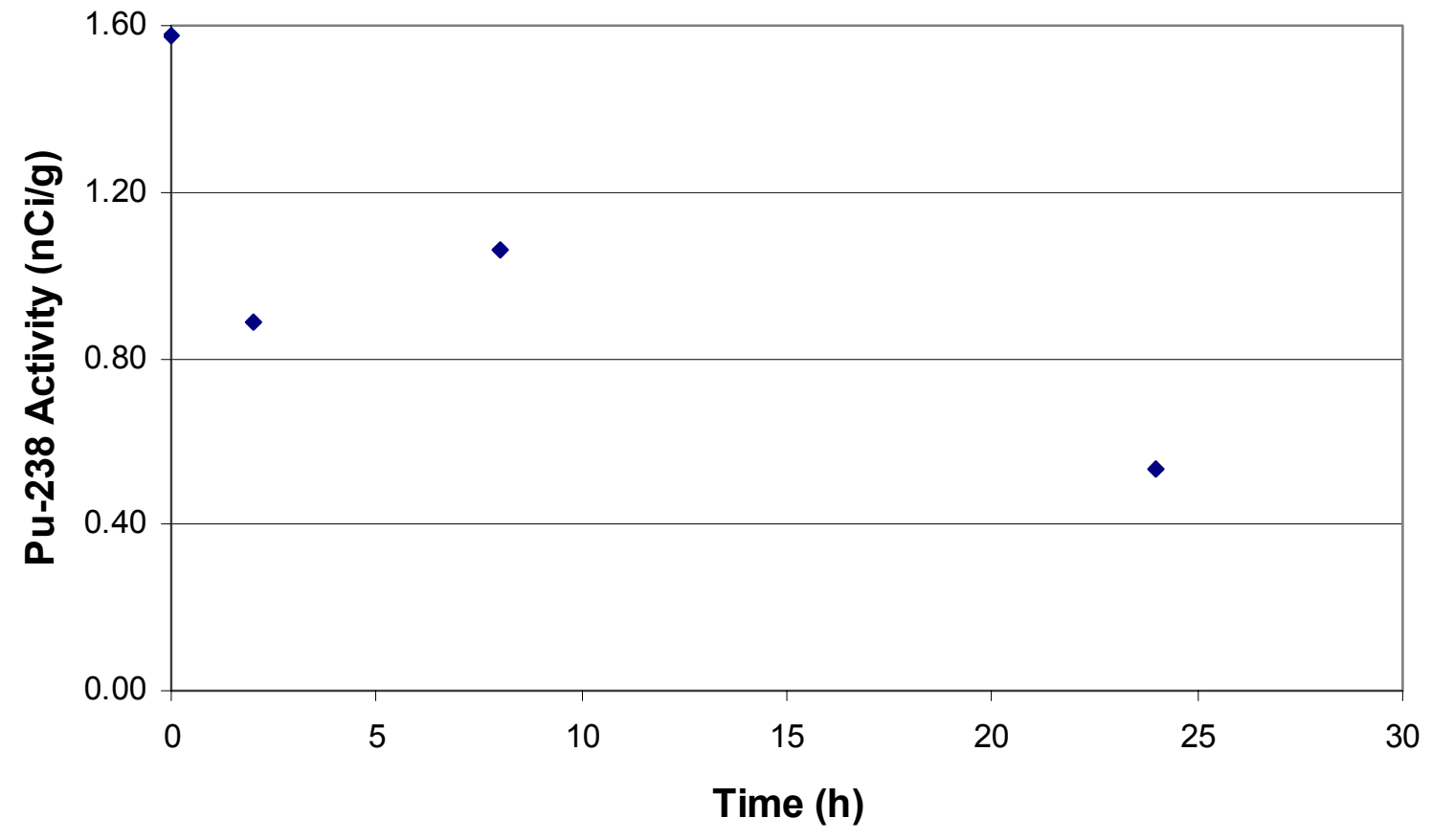

\subsubsection{Strontium Results}

Researchers analyzed the filtered supernates for strontium-90 activity. We did not attempt to confirm the radiostrontium DF by monitoring the total (i.e., including nonradioactive) strontium concentration. Table 16 reports the data while Figure 11 shows the data in graphical form.

Table 16. Strontium-90 Concentration in the Tank 37H Filtrate

\begin{tabular}{|c|c|}
\hline Time (hours) & $90 \mathrm{Sr}(\mathrm{nCi} / \mathrm{g})$ \\
\hline $\begin{array}{c}\text { 0 (just before MST } \\
\text { addition) }\end{array}$ & 1340 \\
\hline 1 & 640 \\
\hline 2 & 714 \\
\hline 4 & 732 \\
\hline 8 & 624 \\
\hline 24 & 552 \\
\hline 26 & 473 \\
\hline 30 & 447 \\
\hline 48 & 351 \\
\hline
\end{tabular}

The data shows a strontium DF of 2.4 achieved in 24 hours, lower than typical for MST removal. The single strike of MST proved insufficient to achieve the SWPF process 
requirement of $40 \mathrm{nCi} / \mathrm{g}$. The plentiful radiostrontium present and the typical moderate analytical uncertainty associated with the values cannot account for the poor results. Insufficient mixing can be discarded as previous tests indicate adequate agitation in the experiment (see section 3.2). At this time, we hypothesize that the initial poor quality of the TNX batch of MST (see section 3.1) is the reason for the poor strontium removal. We note that several actual waste experiments - such as the Tank $37 \mathrm{H}$ work, the "bounding alpha" waste work ${ }^{12}$, the original Tank $37 \mathrm{H} / 44 \mathrm{~F}$ experiment ${ }^{14}$, and the crossflow filter demonstration ${ }^{21}$-- show relatively poor strontium DF behavior. Even the Hydraulically Scaled Demonstration with MST (see section 4.4) shows moderate strontium DF performance and low isothermal absorption performance (see section 4.6).

Figure 11. Strontium-90 Data Throughout the Tank 37H MST Strike

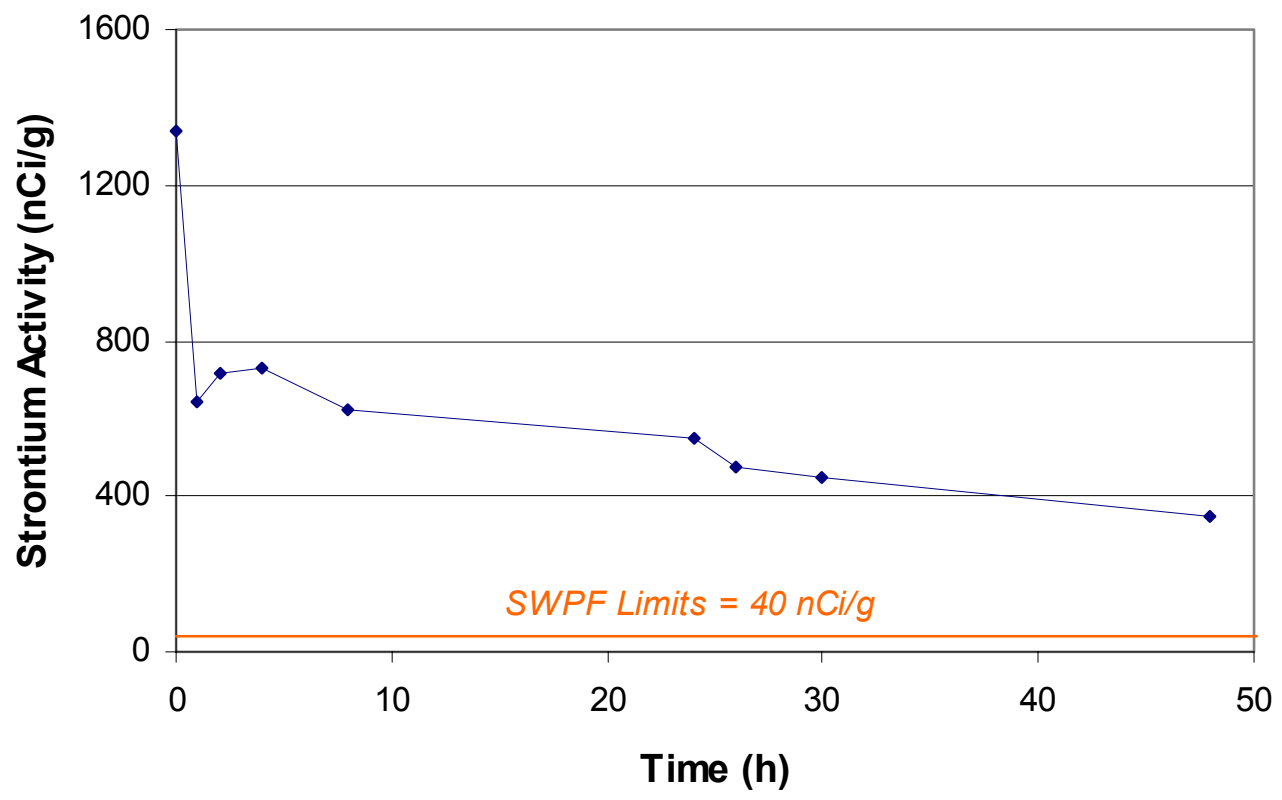

\subsubsection{Neptunium Results}

Researchers analyzed the filtered samples for neptunium-237 activity. Table 17 contains the numerical data. In each case, the neptunium concentration fell below the detection limits of the instrument. Therefore, no observations or conclusions concerning the neptunium data are possible. 
WSRC-TR-2002-00355

Table 17. Neptunium Concentration in the Tank 37H Filtrate

\begin{tabular}{|c|c|}
\hline Time (hours) & $237 \mathrm{~Np}(\mathrm{nCi} / \mathrm{g})$ \\
\hline $\begin{array}{c}0 \text { (just before MST } \\
\text { addition) }\end{array}$ & $<7.06 \mathrm{E}-06$ \\
\hline 1 & $<1.54 \mathrm{E}-05$ \\
\hline 2 & $<1.83 \mathrm{E}-05$ \\
\hline 4 & $<1.31 \mathrm{E}-05$ \\
\hline 8 & $<2.12 \mathrm{E}-05$ \\
\hline 24 & $<1.46 \mathrm{E}-05$ \\
\hline 26 & $<1.39 \mathrm{E}-05$ \\
\hline 30 & $<1.00 \mathrm{E}-05$ \\
\hline 48 & $<1.59 \mathrm{E}-05$ \\
\hline
\end{tabular}

\subsubsection{Uranium Results}

Researchers analyzed filtered samples for uranium (-235 and -238) levels. Table 18 reports the total uranium data while Figure 12 contains the graphical presentation.

Table 18. Total Uranium Concentration in the Tank 37H Filtrate

\begin{tabular}{|c|c|c|c|}
\hline Time (hours) & $235 \mathrm{U}(\mathrm{mg} / \mathrm{L})$ & $238 \mathrm{U}(\mathrm{mg} / \mathrm{L})$ & Activity $\%{ }^{238} \mathrm{U}$ \\
\hline $\begin{array}{c}\text { (just before } \mathrm{MST} \\
\text { addition) }\end{array}$ & 0.061 & 0.67 & $91.6 \%$ \\
\hline 1 & 0.051 & 1.96 & $97.5 \%$ \\
\hline 2 & $<0.050$ & 0.53 & $>91.3 \%$ \\
\hline 4 & $<0.036$ & 0.46 & $>92.8 \%$ \\
\hline 8 & $<0.058$ & 0.66 & $>91.9 \%$ \\
\hline 24 & $<0.040$ & 0.48 & $>92.3 \%$ \\
\hline 26 & 0.040 & 0.92 & $95.8 \%$ \\
\hline 30 & 0.039 & 0.73 & $94.9 \%$ \\
\hline 48 & $<0.044$ & 1.07 & $>96.1 \%$ \\
\hline
\end{tabular}

As with the plutonium results, the tabular data shows a wide variation in the uranium results, and more importantly, the isotopic distribution. Again, we attribute this to random contamination from the cells. To attempt an evaluation of the performance of MST, we restrict the analysis to that subset of the data free of suspect contamination - the same data points we use in the analysis of the plutonium results: values at $0,2,8$, and 24 hours. Figure 12 displays this subset of "qualified" data. Based on this (i.e., the 0 and 24 hour points), the treatment yielded an approximate DF of 1.4. 
WSRC-TR-2002-00355

Figure 12. Total Uranium Activity in the Tank 37H Solution (absent suspected contaminated data)

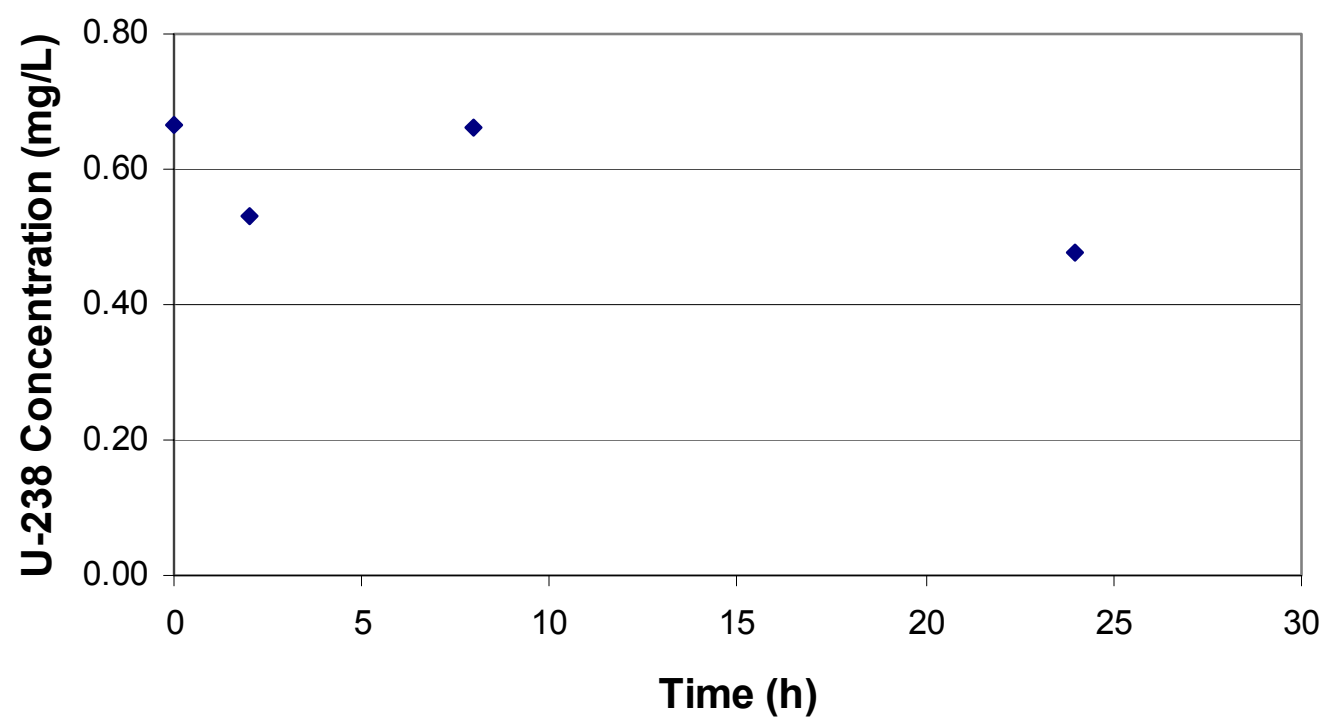

\subsection{Hydraulically Scaled MST Demonstration}

The hydraulically scaled demonstration with MST used mixing conditions typical of the ARP reactor. As a way of determining the influence of large-scale equipment, we compared our results to work by Hobbs, who performed a similar set of MST tests, but using an orbital shaker. Hobbs' work involved a smaller scale $(100 \mathrm{~mL})$ reaction in an orbital shaker using the same salt solution and MST as used in the Hydraulically Scaled MST Demonstration.

\subsubsection{Plutonium Removal Efficiency}

Researchers analyzed the filtered samples for total plutonium $\left({ }^{238} \mathrm{Pu}+{ }^{239 / 240} \mathrm{Pu}\right)$. Table 19 shows these plutonium results and Hobbs' results while Figure 13 shows the graphical results. Mass data for the plutonium appears in Appendix 4. 
WSRC-TR-2002-00355

Table 19. Total Plutonium Concentrations in the MST Demonstration Filtrate

\begin{tabular}{|c|c|c|c|}
\hline & Experiment & Control & Hobbs \\
\hline Time (hours) & Total $\mathrm{Pu}(\mathrm{nCi} / \mathrm{g})$ & Total $\mathrm{Pu}(\mathrm{nCi} / \mathrm{g})$ & $239 / 240 \mathrm{Pu}(\mathrm{nCi} / \mathrm{g})$ \\
\hline 0 (before MST addition) & 0.248 & 0.222 & 0.164 \\
\hline 2 & 0.0842 & 0.236 & $\mathrm{NA}$ \\
\hline 4 & 0.0884 & 0.240 & $\mathrm{NA}$ \\
\hline 12 & 0.0781 & 0.251 & $\mathrm{NA}$ \\
\hline 18 & 0.0616 & 0.216 & $\mathrm{NA}$ \\
\hline 24 & 0.0641 & 0.215 & 0.0398 \\
\hline 30 & 0.0602 & 0.260 & $\mathrm{NA}$ \\
\hline
\end{tabular}

Figure 13. Total Plutonium in the MST Demonstration Filtrate Over Time

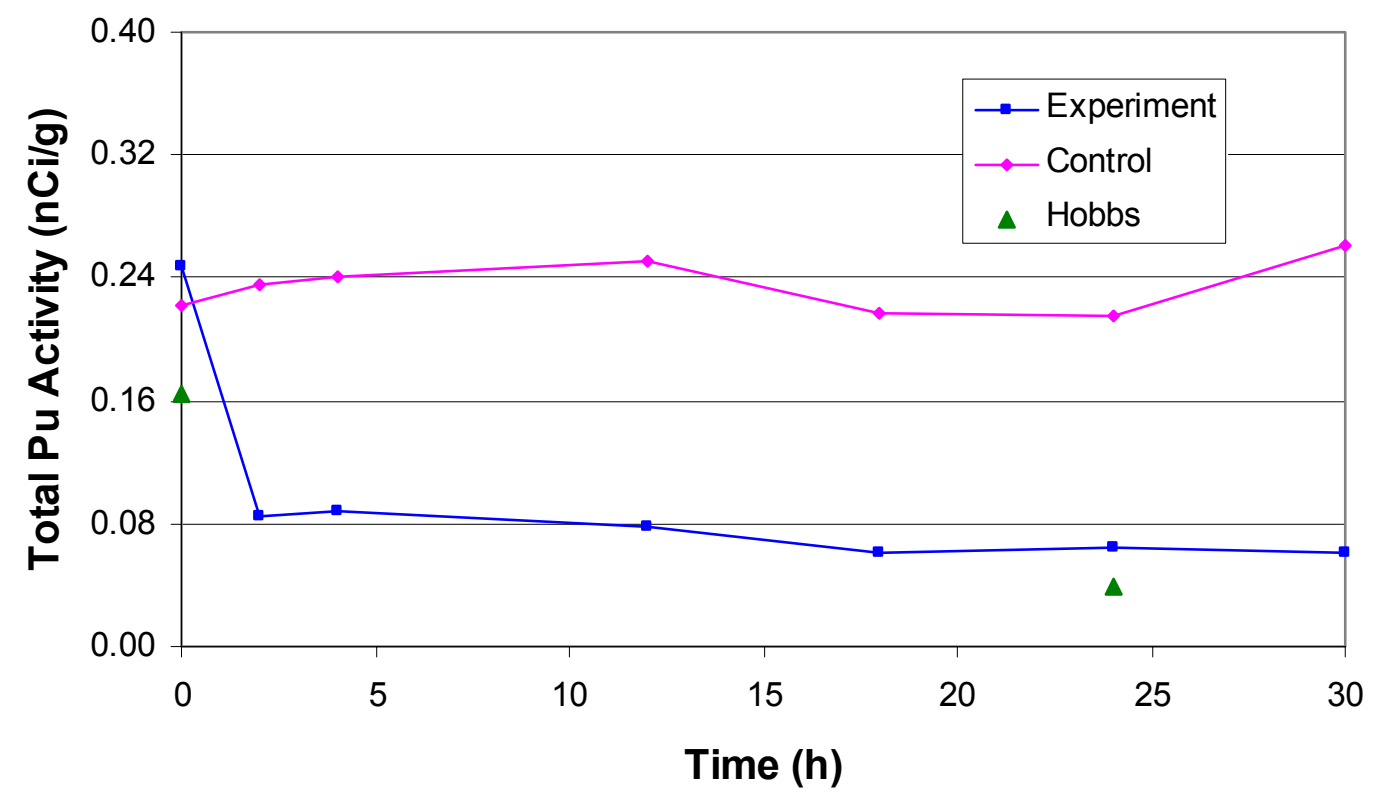

The total plutonium data indicates a DF of 3.9 achieved after 24 hours and largely achieved early on. This is a good DF match to the test results from Hobbs' work of 4.1.

\subsubsection{Strontium Removal Efficiency}

Researchers analyzed the filtered solutions for strontium- 85 . Table 20 shows these strontium results and Hobbs' results while Figure 14 shows the graphical results. Mass data for the strontium appears in Appendix 4. 
WSRC-TR-2002-00355

Table 20. Strontium-85 Concentration in the MST Demonstration Filtrate

\begin{tabular}{|c|c|c|c|}
\hline & Experiment & Control & Hobbs \\
\hline Time (hours) & ${ }^{85} \mathrm{Sr}(\mathrm{nCi} / \mathrm{g})$ & ${ }^{85} \mathrm{Sr}(\mathrm{nCi} / \mathrm{g})$ & ${ }^{85} \mathrm{Sr}(\mathrm{nCi} / \mathrm{g})$ \\
\hline 0 (before MST addition) & 12.2 & 12.8 & 9.07 \\
\hline 2 & 0.553 & 12.4 & NA \\
\hline 4 & 0.672 & 12.2 & NA \\
\hline 12 & 0.490 & 12.4 & NA \\
\hline 18 & 0.427 & 11.7 & NA \\
\hline 24 & 0.430 & 12.0 & 0.238 \\
\hline 30 & 0.451 & 13.9 & NA \\
\hline
\end{tabular}

Figure 14. Strontium-85 in MST Demonstration Filtrate

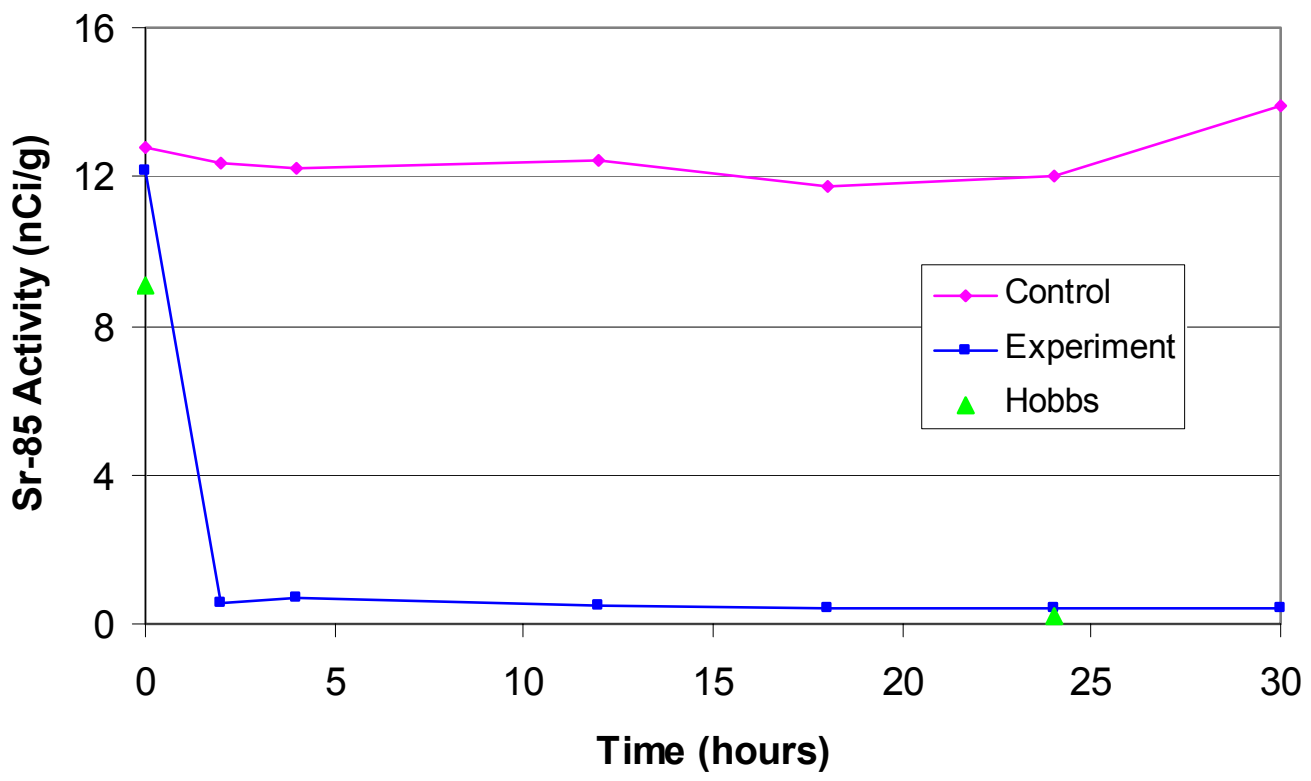

The data shows a rapid decline of strontium-85 in solution over a short time ( $\leq 2$ hours), with essentially no change after that point. This gives a DF of 28 over a 24 hour time period. This DF is comparable to the DF of 38 obtained from Hobbs' work. We also monitored the non-radioactive strontium values as a check against the ${ }^{85} \mathrm{Sr}$ data. We measured the mass of non-radioactive strontium $\left({ }^{88} \mathrm{Sr}\right)$ using ICP-MS.

Table 21 shows the ${ }^{88} \mathrm{Sr}$ data in tabular form while Figure 15 shows the ${ }^{88} \mathrm{Sr}$ data in graphical form. 
WSRC-TR-2002-00355

Table 21. Strontium (mass 88) Concentration in the MST Demonstration Filtrate

\begin{tabular}{|c|c|c|}
\hline & Experiment & Control \\
\hline Time (hours) & ${ }^{88} \mathrm{Sr}(\mathrm{mg} / \mathrm{L})$ & ${ }^{88} \mathrm{Sr}(\mathrm{mg} / \mathrm{L})$ \\
\hline 0 (before MST addition) & 0.170 & 0.179 \\
\hline 2 & 0.0176 & 0.190 \\
\hline 4 & 0.0139 & 0.212 \\
\hline 12 & 0.0110 & 0.212 \\
\hline 18 & 0.0142 & 0.198 \\
\hline 24 & 0.0126 & 0.206 \\
\hline 30 & 0.0130 & 0.224 \\
\hline
\end{tabular}

Figure 15. Strontium (by Mass 88) in the MST Demonstration Filtrate

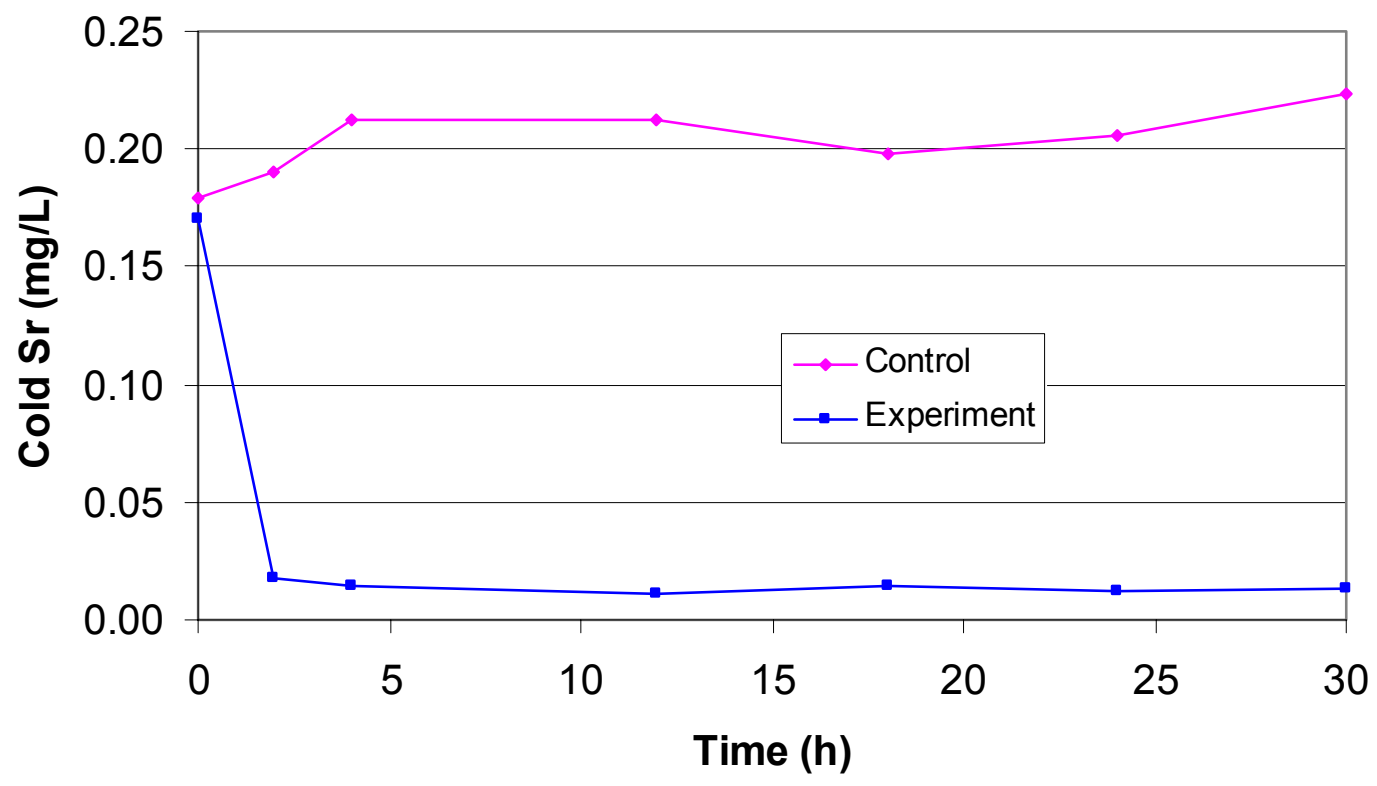

This strontium data shows an analogous rapid falloff in concentration as the previous strontium data, however yielding a DF at 24 hours of 13 compared to a value of 28 by the other measurement. Radiocounting analytical error can not account for this large discrepancy. At this time we think the divergence in the radioactive and non-radioactive strontium results is due to analytical variances in the ICP-MS resulting from the dilution factors needed to determine the non-radioactive strontium concentrations. 
WSRC-TR-2002-00355

\subsubsection{Neptunium Removal Efficiency}

Researchers analyzed the filtered solutions for neptunium-237. Table 22 shows these neptunium results and Hobbs' data while Figure 16 shows the graphical results.

Table 22. Neptunium-237 Concentration in the MST Demonstration Filtrate

\begin{tabular}{|c|c|c|c|}
\hline & Experiment & Control & Hobbs \\
\hline Time (hours) & ${ }^{237} \mathrm{~Np}(\mathrm{nCi} / \mathrm{g})$ & ${ }^{237} \mathrm{~Np}(\mathrm{nCi} / \mathrm{g})$ & ${ }^{237} \mathrm{~Np}(\mathrm{nCi} / \mathrm{g})$ \\
\hline 0 (before MST addition) & 0.184 & 0.179 & 0.212 \\
\hline 2 & 0.0999 & 0.174 & NA \\
\hline 4 & 0.0863 & 0.201 & NA \\
\hline 12 & 0.0761 & 0.187 & NA \\
\hline 18 & 0.0713 & 0.179 & NA \\
\hline 24 & 0.0728 & 0.187 & 0.0785 \\
\hline 30 & 0.0426 & 0.204 & NA \\
\hline
\end{tabular}

Figure 16. Neptunium-237 in the MST Demonstration Filtrate

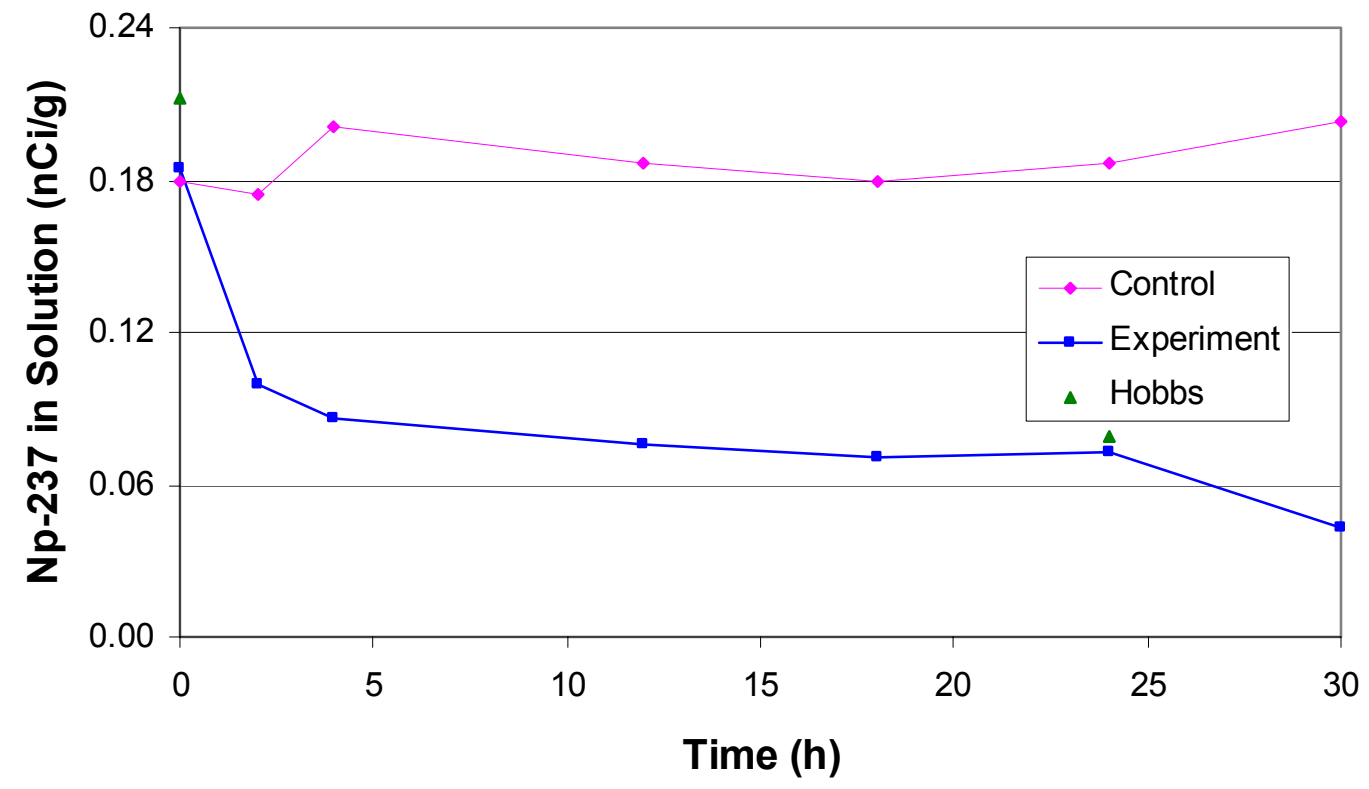

The neptunium-237 data shows the expected trend in removal. By 24 hours, the data shows a DF of 2.5. This DF is a good match with the DF of 2.7 from Hobbs' work. 
WSRC-TR-2002-00355

\subsubsection{Uranium Removal Efficiency}

Researchers analyzed the filtered solutions for total uranium $\left({ }^{235} U+{ }^{238} U\right)$. Table 23 shows these uranium results while Figure 17 shows the graphical results.

Table 23. Total Uranium in the MST Demonstration Filtrate

\begin{tabular}{|c|c|c|c|}
\hline & Experiment & Control & Hobbs \\
\hline Time (hours) & Total U (mg/L) & Total U (mg/L) & Total U(mg/L) \\
\hline 0 (before MST addition) & 12.5 & 11.8 & 12.9 \\
\hline 2 & 11.1 & 12.1 & NA \\
\hline 4 & 11.1 & 12.2 & NA \\
\hline 12 & 11.2 & 13.1 & NA \\
\hline 18 & 11.5 & 12.2 & NA \\
\hline 24 & 10.7 & 12.5 & 9.78 \\
\hline 30 & 11.2 & 13.0 & NA \\
\hline
\end{tabular}

Figure 17. Total Uranium Concentration the MST Demonstration Filtrate

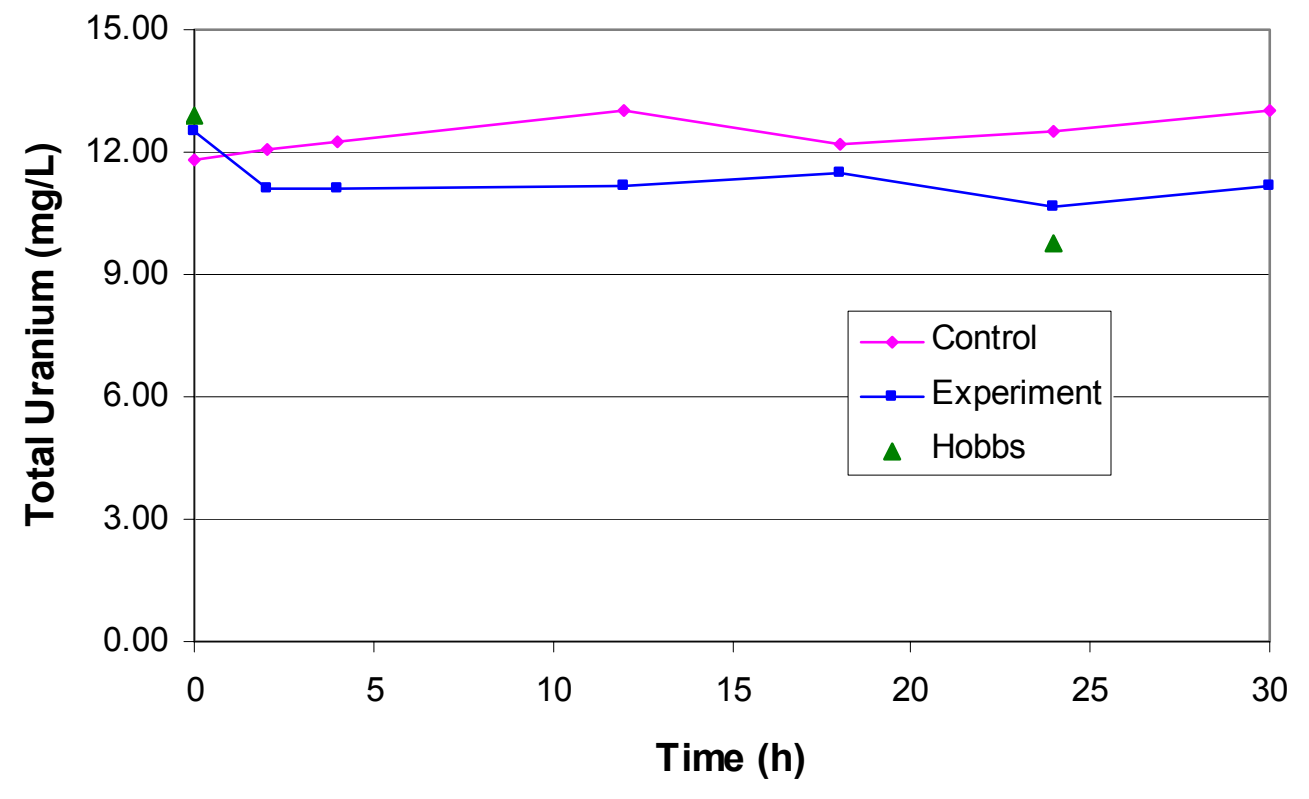

As expected, the uranium levels in solution proved largely insensitive to the addition of the MST. After 24 hours, the DF reached a value of 1.2, which falls within the range of prior studies. Hobbs' similar test result provided a DF value of 1.3. 
4.4.5 Cesium Concentrations During the Test

While cesium is not sorbed by MST, researchers tracked the ${ }^{137} \mathrm{Cs}$ concentration over the duration of the test. As the cesium concentration should remain constant, any notable changes would indicate an upset (evaporation, accidental addition of chemical contaminants, etc) in the system. Table 24 shows these cesium results while Figure 18 shows the graphical results.

Table 24. Cesium Activity in the MST Demonstration Filtrate

\begin{tabular}{|c|c|c|}
\hline & Experiment & Control \\
\hline Time (hours) & ${ }^{137} \mathrm{Cs}(\mathrm{nCi} / \mathrm{g})$ & ${ }^{137} \mathrm{Cs}(\mathrm{nCi} / \mathrm{g})$ \\
\hline 0 (before MST addition) & 1.06 & 1.28 \\
\hline 2 & 1.26 & 1.23 \\
\hline 4 & 1.21 & 1.17 \\
\hline 12 & 1.24 & 1.27 \\
\hline 18 & 1.35 & 1.25 \\
\hline 24 & 1.19 & 1.20 \\
\hline 30 & 1.34 & 1.33 \\
\hline
\end{tabular}

Figure 18. Cesium Activity in the MST Demonstration Filtrate

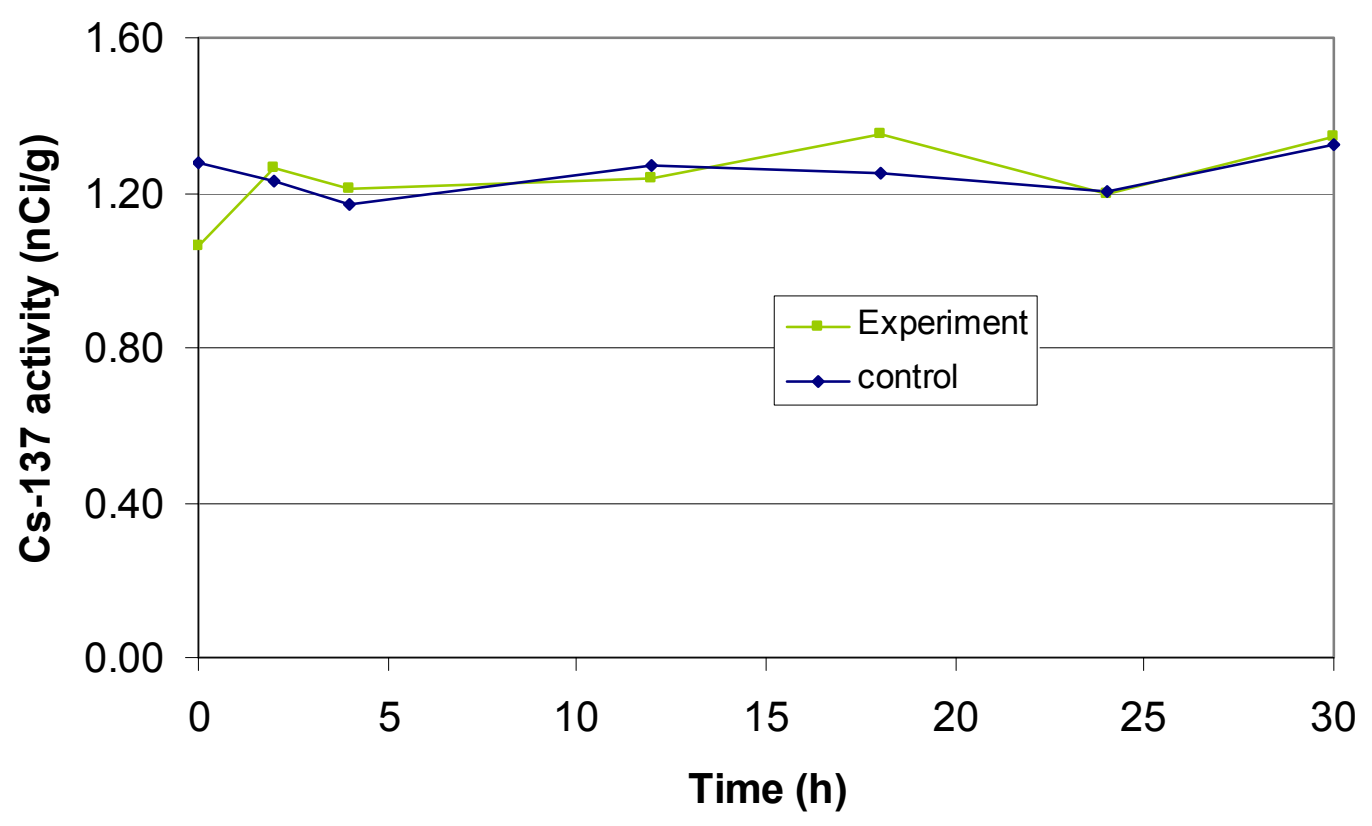

Both the control and the experimental data show essentially no change in the cesium activity over time. This confirms our assertion that the system encountered no major upsets over the duration. 
WSRC-TR-2002-00355

\subsection{Hydraulically Scaled Permanganate Demonstration}

The second hydraulically scaled demonstration used sodium permanganate, hydrogen peroxide (as a reductant for the permanganate), and strontium nitrate to remove the strontium and actinides. The experiment examined the efficiency of the process at conditions typical of the ARP reactor. Taken together, the two demonstrations provide nearly a direct comparison of the MST and permanganate processes. One difference between the two demonstrations is that during the equilibrium period in the permanganate demonstration, we added DDI water at 43 days to replace evaporative losses.

\subsubsection{Plutonium Removal Efficiency}

Researchers analyzed the filtered solutions for total plutonium $\left({ }^{238} \mathrm{Pu}+{ }^{239 / 240} \mathrm{Pu}\right)$. Table 25 shows these plutonium results while Figure 19 shows the graphical results.

Table 25. Total Plutonium in the $\mathrm{MnO}_{4}$ Demonstration Filtrate

\begin{tabular}{|c|c|c|c|c|}
\hline & Experiment & Experiment & Control & Control \\
\hline Time (hours) & $238 \mathrm{Pu}(\mathrm{nCi} / \mathrm{g})$ & $239 / 40 \mathrm{Pu}(\mathrm{nCi} / \mathrm{g})$ & $238 \mathrm{Pu}(\mathrm{nCi} / \mathrm{g})$ & $239 / 40 \mathrm{Pu}(\mathrm{nCi} / \mathrm{g})$ \\
\hline $0^{*}$ & 0.0951 & 2.09 & 0.0473 & 0.981 \\
\hline 2 & 0.0752 & 1.61 & 0.0732 & 1.39 \\
\hline 4 & 0.271 & 1.65 & 0.0964 & 2.06 \\
\hline 12 & 0.0567 & 1.34 & 0.0968 & 2.44 \\
\hline 18 & 0.0634 & 1.25 & 0.0468 & 1.06 \\
\hline 24 & 0.0520 & 1.29 & 0.0606 & 1.05 \\
\hline 30 & 0.0732 & 1.28 & 0.0431 & 0.908 \\
\hline
\end{tabular}

* The time $=0$ data are before the $\mathrm{MnO}_{4} / \mathrm{H}_{2} \mathrm{O}_{2}$ addition.

The results show a non-intuitive behavior. While the experimental data indicates a DF of 1.6, the control data is nonsensical. Analytical uncertainty is not the cause of this problem. At this time we conclude that plutonium instability led to inconclusive results. A further discussion occurs in Appendix 5. 
Figure 19. Total Plutonium in the $\mathrm{MnO}_{4}$ Demonstration Filtrate

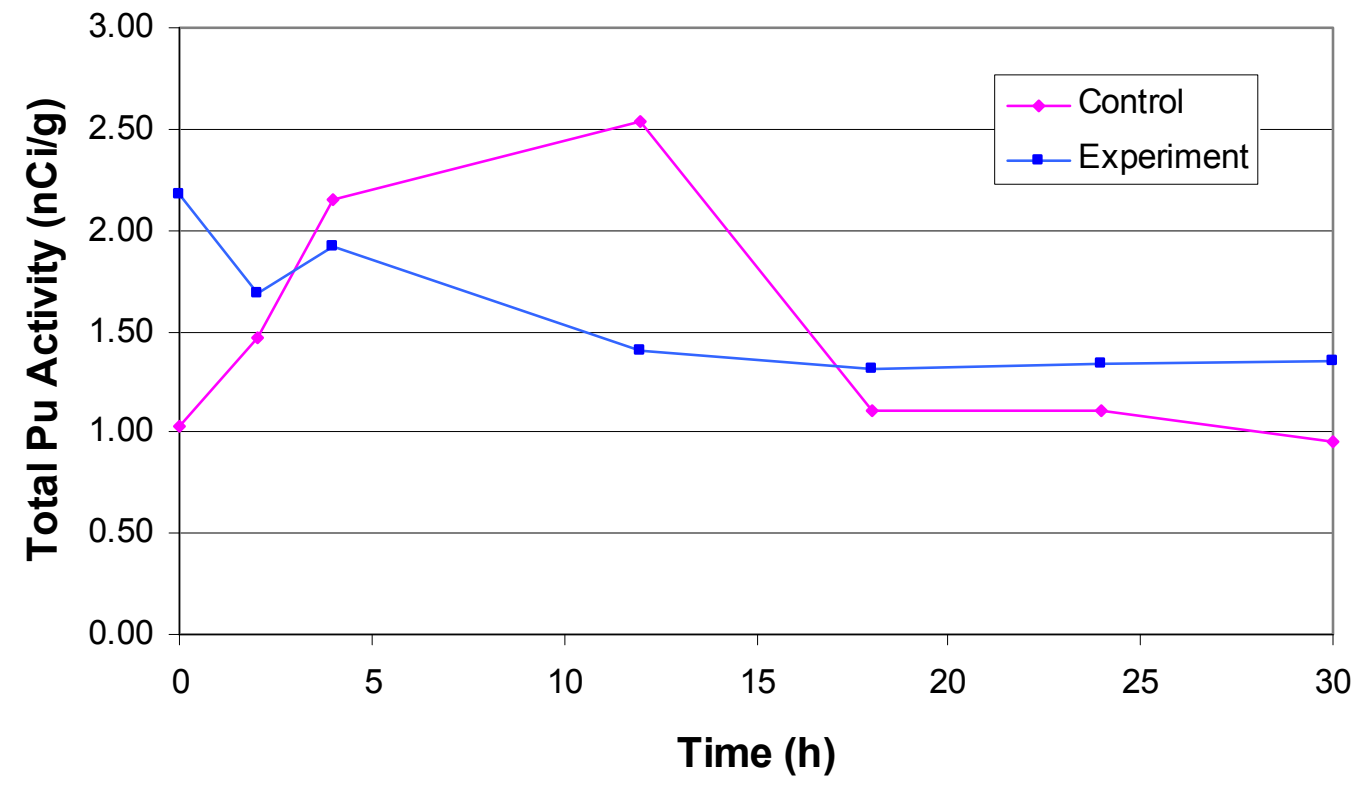

\subsubsection{Strontium Removal Efficiency}

Researchers analyzed the filtered solutions for strontium-85. Table 26 shows these strontium results while Figure 20 shows the graphical results.

Table 26. Strontium-85 Concentration in the $\mathrm{MnO}_{4}$ Demonstration Filtrate

\begin{tabular}{|c|c|c|}
\hline & Experiment & Control \\
\hline $\begin{array}{c}\text { Time (hours) } \\
\text { (before } \mathrm{MnO}_{4} / \mathrm{H}_{2} \mathrm{O}_{2} \\
\text { addition) }\end{array}$ & ${ }^{85} \mathrm{Sr}(\mathrm{nCi} / \mathrm{g})$ & ${ }^{85} \mathrm{Sr}(\mathrm{nCi} / \mathrm{g})$ \\
\hline 2 & 6.48 & 6.26 \\
\hline 4 & $<0.0619$ & 6.36 \\
\hline 12 & $<0.0626$ & 6.46 \\
\hline 18 & $<0.0563$ & 6.74 \\
\hline 24 & $<0.0625$ & 6.03 \\
\hline 30 & $<0.0619$ & 6.25 \\
\hline & $<0.0592$ & 6.55 \\
\hline
\end{tabular}


Figure 20. Strontium-85 in the $\mathrm{MnO}_{4}$ Demonstration Filtrate

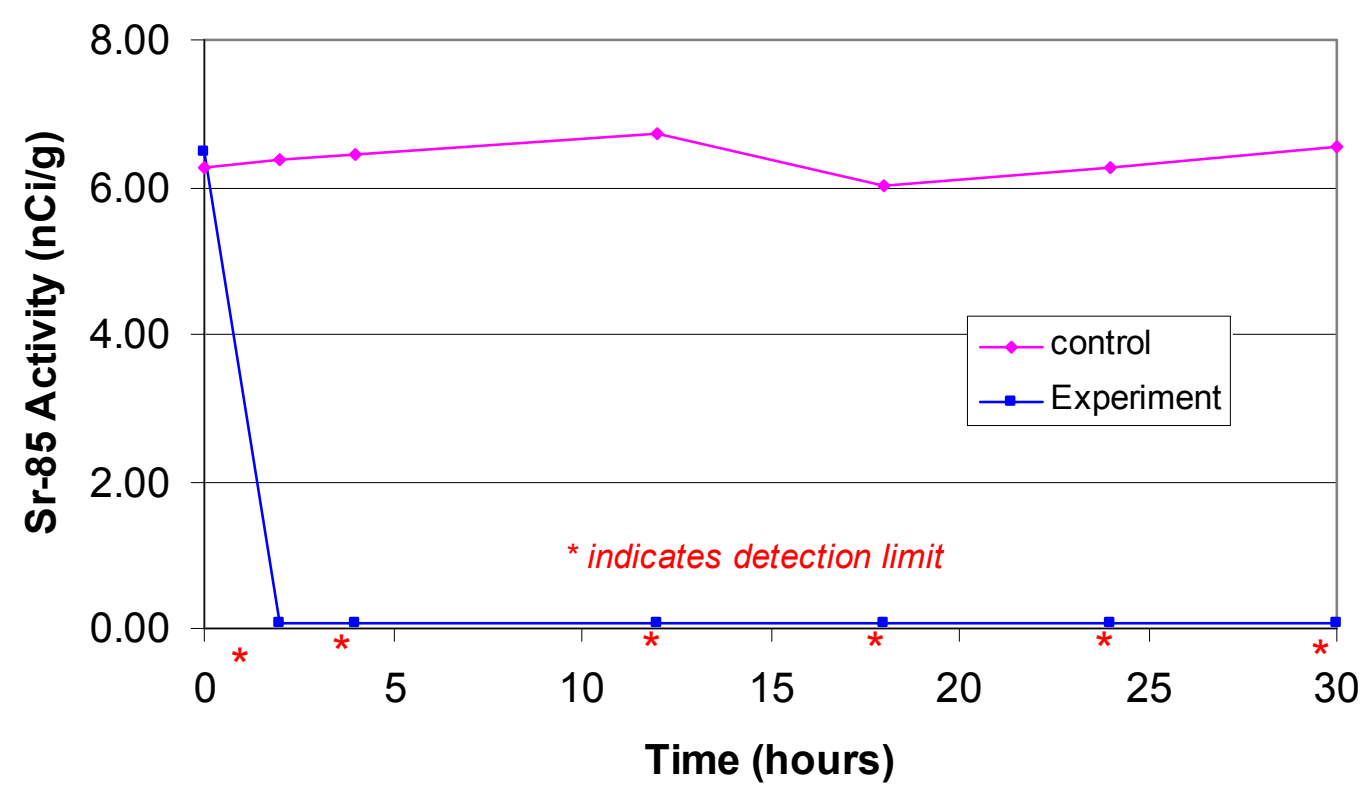

The data shows a similar trend as in the MST test. The drop in strontium concentration occurs rapidly, and in this case, the concentration falls below instrument detection limits for the remainder of the experiment. The data indicates a DF of $>105$ by 24 hours.

\subsubsection{Neptunium Removal Efficiency}

Researchers analyzed the filtered solutions for neptunium-237. Table 27 shows these neptunium results while Figure 21 shows the graphical results.

After 24 hours, the neptunium data indicates a DF of 1.5.

Table 27. Neptunium-237 Concentration in the $\mathrm{MnO}_{4}$ Demonstration Filtrate

\begin{tabular}{|c|c|c|}
\hline & Experiment & Control \\
\hline Time (hours) & ${ }^{237} \mathrm{~Np}(\mathrm{nCi} / \mathrm{g})$ & ${ }^{237} \mathrm{~Np}(\mathrm{nCi} / \mathrm{g})$ \\
\hline $\begin{array}{c}0 \text { (before } \mathrm{MnO}_{4} / \mathrm{H}_{2} \mathrm{O}_{2} \\
\text { addition) }\end{array}$ & 0.250 & 0.245 \\
\hline 2 & 0.140 & 0.262 \\
\hline 4 & 0.143 & 0.242 \\
\hline 12 & 0.164 & 0.235 \\
\hline 18 & 0.163 & 0.232 \\
\hline 24 & 0.168 & 0.246 \\
\hline 30 & 0.156 & 0.258 \\
\hline
\end{tabular}


Figure 21. Neptunium-237 in the $\mathrm{MnO}_{4}$ Demonstration Filtrate

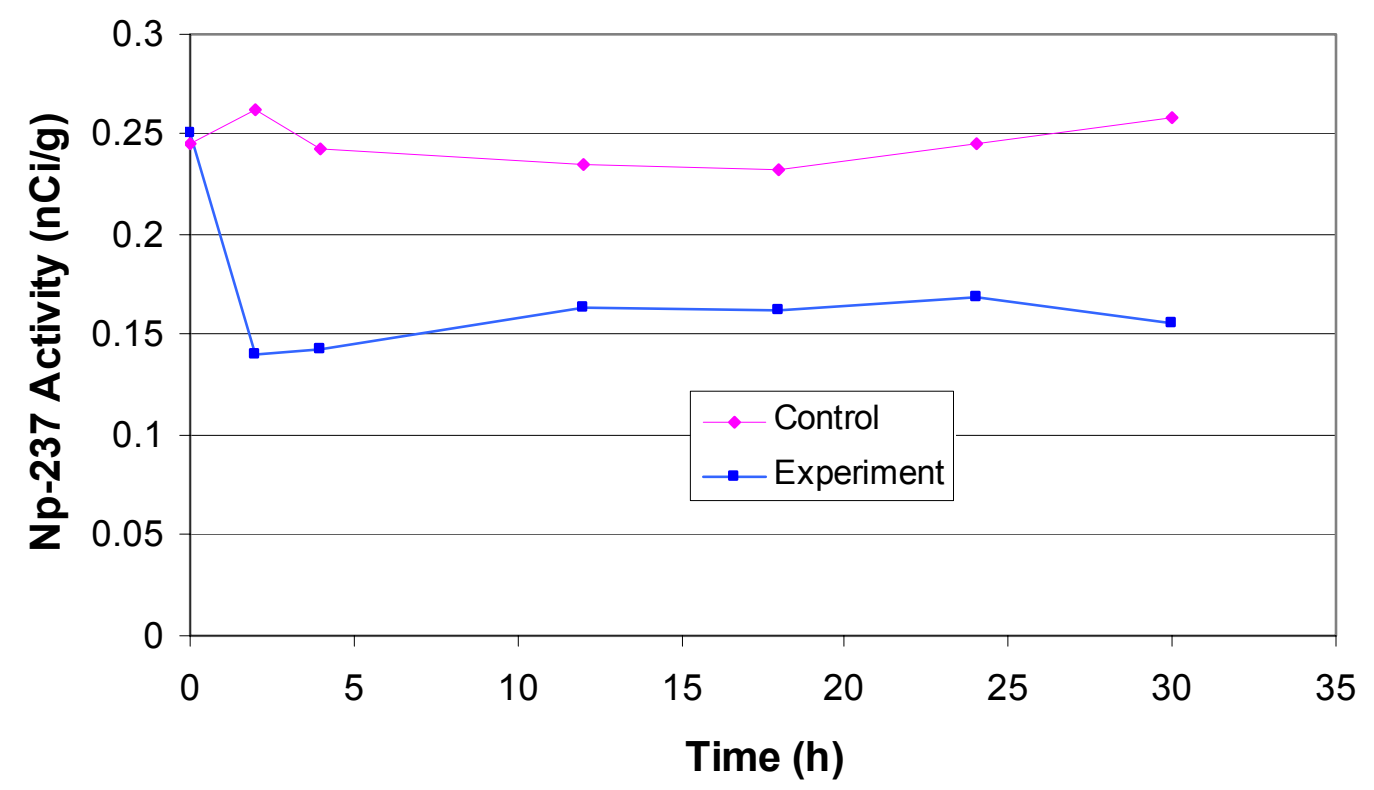

4.5.4 Uranium Removal Efficiency

Researchers analyzed the filtered solutions for total uranium $\left({ }^{235} U+{ }^{238} U\right)$. Table 28 shows these uranium results while Figure 22 shows the graphical results.

Table 28. Total Uranium in the $\mathrm{MnO}_{4}$ Demonstration Filtrate

\begin{tabular}{|c|c|c|}
\hline & Experiment & Control \\
\hline Time (hours) & Total U (mg/L) & Total U (mg/L) \\
\hline $\begin{array}{c}\text { 0 (before } \mathrm{MnO}_{4} / \mathrm{H}_{2} \mathrm{O}_{2} \\
\text { addition) }\end{array}$ & 21.1 & 20.6 \\
\hline 2 & 18.0 & 21.1 \\
\hline 4 & 17.8 & 20.1 \\
\hline 12 & 19.0 & 20.1 \\
\hline 18 & 18.9 & 20.8 \\
\hline 24 & 17.7 & 19.8 \\
\hline 30 & 16.8 & 19.8 \\
\hline
\end{tabular}


WSRC-TR-2002-00355

Figure 22. Total Uranium Concentration in the $\mathrm{MnO}_{4}$ Demonstration Filtrate

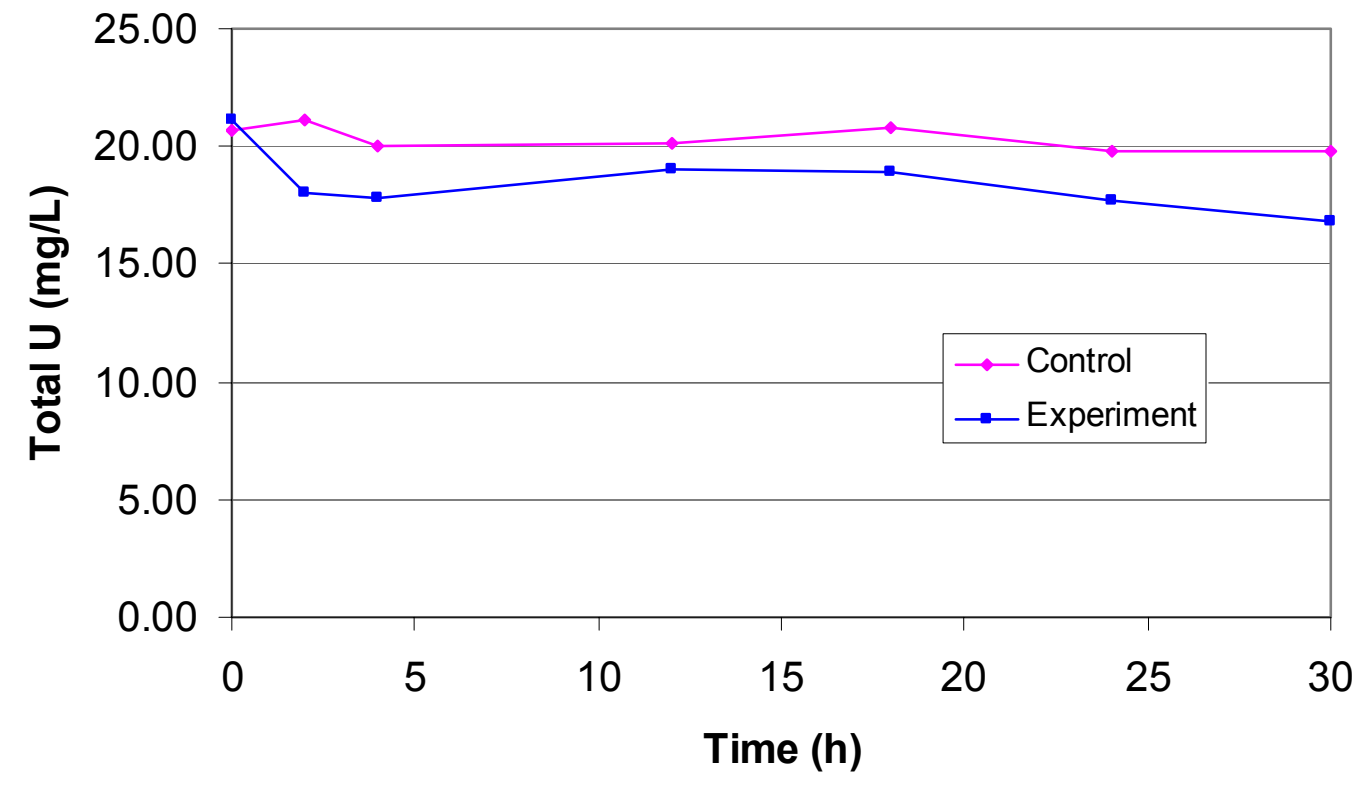

As expected, the uranium levels in solution proved largely insensitive to the addition of the permanganate. After 24 hours, the system achieved a DF of 1.2.

4.5.5 Cesium Concentrations during the Test As with the first Hydraulically Scaled Demonstration, researchers tracked the ${ }^{137} \mathrm{Cs}$ concentration over the duration of the test. Table 29 shows these plutonium results while Figure 23 shows the graphical results.

Table 29. Cesium Activity in Solution

\begin{tabular}{|c|c|c|}
\hline & Experiment & Control \\
\hline $\begin{array}{c}\text { Time (hours) } \\
\text { (before } \mathrm{MnO}_{4} / \mathrm{H}_{2} \mathrm{O}_{2} \\
\text { addition) }\end{array}$ & 1.05 & 1.01 \\
\hline 2 & 0.995 & 1.03 \\
\hline 4 & 0.995 & 0.972 \\
\hline 12 & 0.995 & 0.959 \\
\hline 18 & 0.958 & 1.04 \\
\hline 24 & 0.981 & 1.09 \\
\hline 30 & 1.00 & 1.08 \\
\hline
\end{tabular}


WSRC-TR-2002-00355

Figure 23. Cesium Activity in the $\mathrm{MnO}_{4}$ Demonstration Filtrate

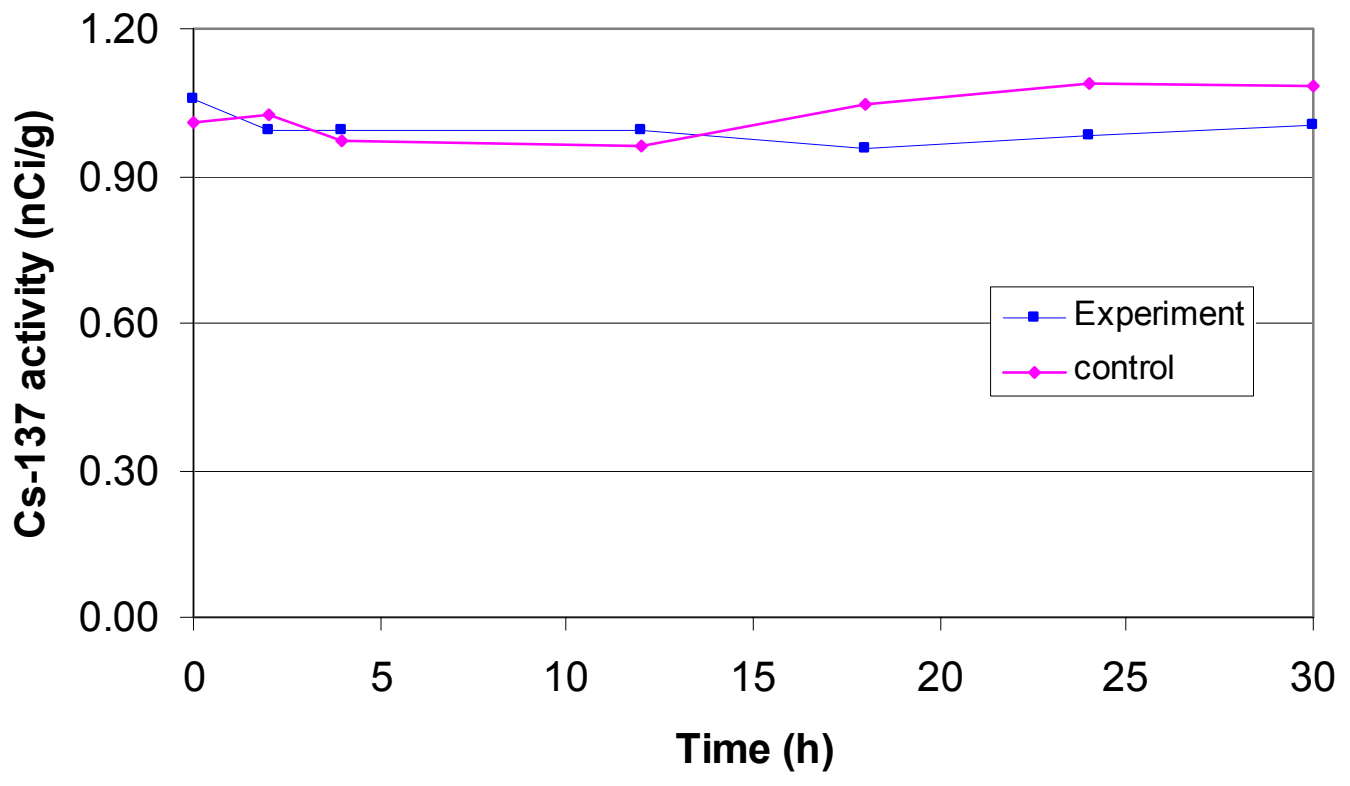

Both the control and the experimental data show essentially no change in the cesium activity over time. This confirms our assertion that the system encountered no major upsets over the duration.

\subsection{MST Isotherms and Comparison with Prior Studies}

As the actinides and strontium concentrations increase, sorption behavior onto MST will appear increasingly nonlinear making the DF concept less useful for interpretation of the data. In such cases, one must resort to reviewing the data in terms of sorption isotherms. While providing a detailed explanation of isotherm modeling falls outside the scope of this report, we present here the plutonium and strontium data contained in this document as well as previous data as a comparison.

An adsorption isotherm plot expresses the amount of substance adsorbed per unit weight of adsorbent, $\mathrm{q}_{\mathrm{e}}$, as a function of the residual equilibrium concentration, $\mathrm{C}_{\mathrm{e}}$, of the substance remaining in the solution phase. Commonly, the amount of adsorbed material per unit weight of adsorbent, $\mathrm{q}_{\mathrm{e}}$, increases with increasing concentration, $\mathrm{C}_{\mathrm{e}}$, but not always in direct proportion. Several equilibrium models exist to describe adsorption isotherm relationships. Experimental isotherms are useful for describing adsorption capacity to facilitate evaluation of the feasibility of the process for a given application. (However, absorption isotherm plots prove less useful for the permanganate process since precipitation appears the dominant method for removing radionuclides from waste by that technology.). 
WSRC-TR-2002-00355

Figure 24 presents plutonium data from this document ("T37H/44F Reanalysis", "Hydraulically Scaled Demo - MST") and compares the data to values from other work. Appendix 4 contains the mass data for the relevant data points from this document. The plot of all the data seems to indicate that the data roughly fits a Langmuir model. From the good fit of the data, we conclude that one can use prior data to predict future plutonium sorption behavior with reasonable confidence.

While we can perform the same type of analysis with strontium, we have more limited data sets available since most studies did not measure the non-radioactive strontium present. To create the isotherm absorption plot, we need to know the total strontium concentration, as the sorbent will remove both radioactive and non-radioactive strontium equally well.

Figure 24. Isotherm of Plutonium Loading on MST

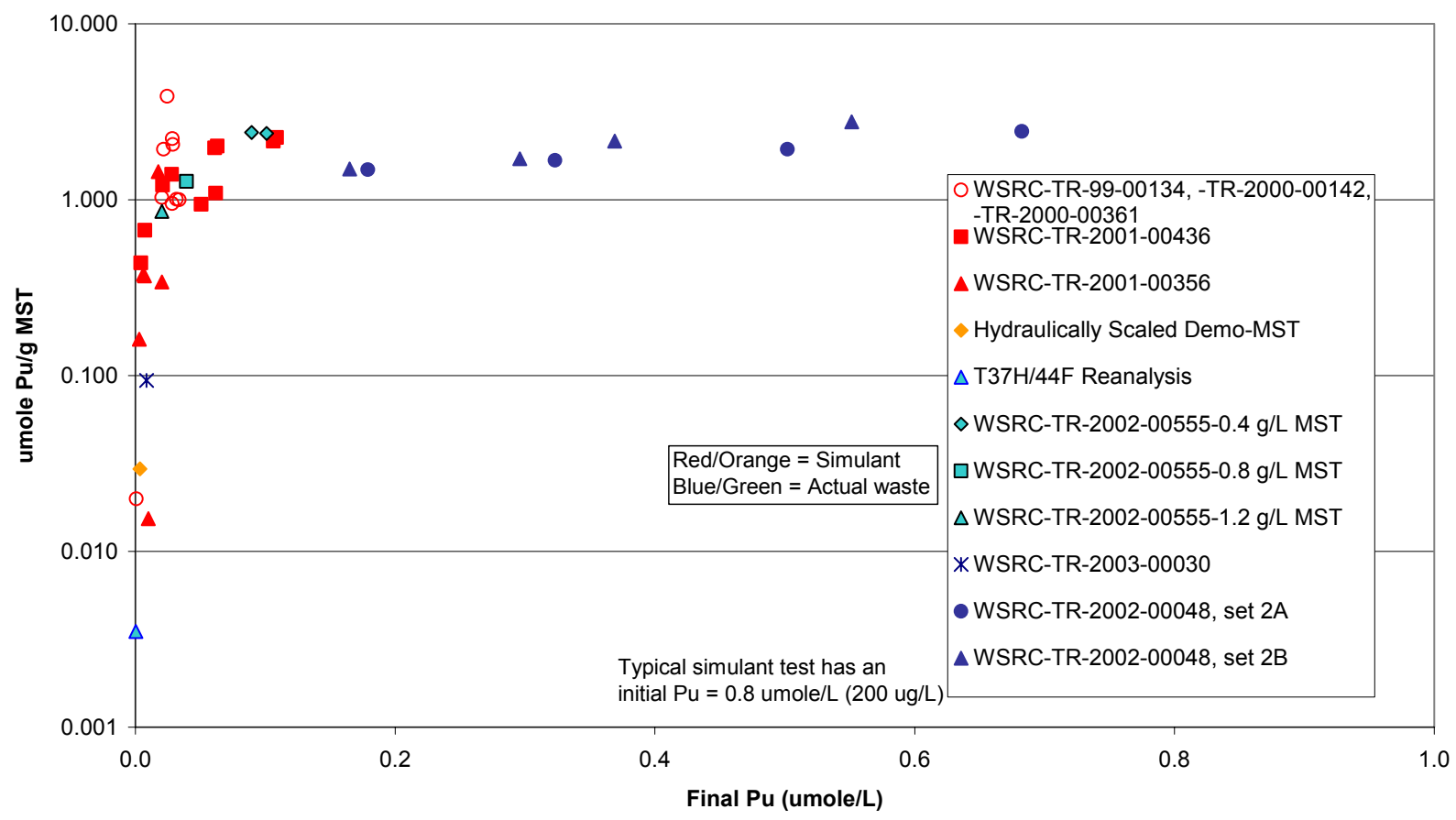


Figure 25 presents strontium data from this document ("Hydraulically Scaled Demo MST") and compares the data to values from other work. Appendix 4 contains the mass data for the relevant data points from this document. The one data point we add to previous work deviates markedly from other data points. We currently believe that the poor performance for strontium removal in this test reflects the degraded condition of the MST available for experiments.

\section{Figure 25. Isotherm of Strontium Loading on MST}

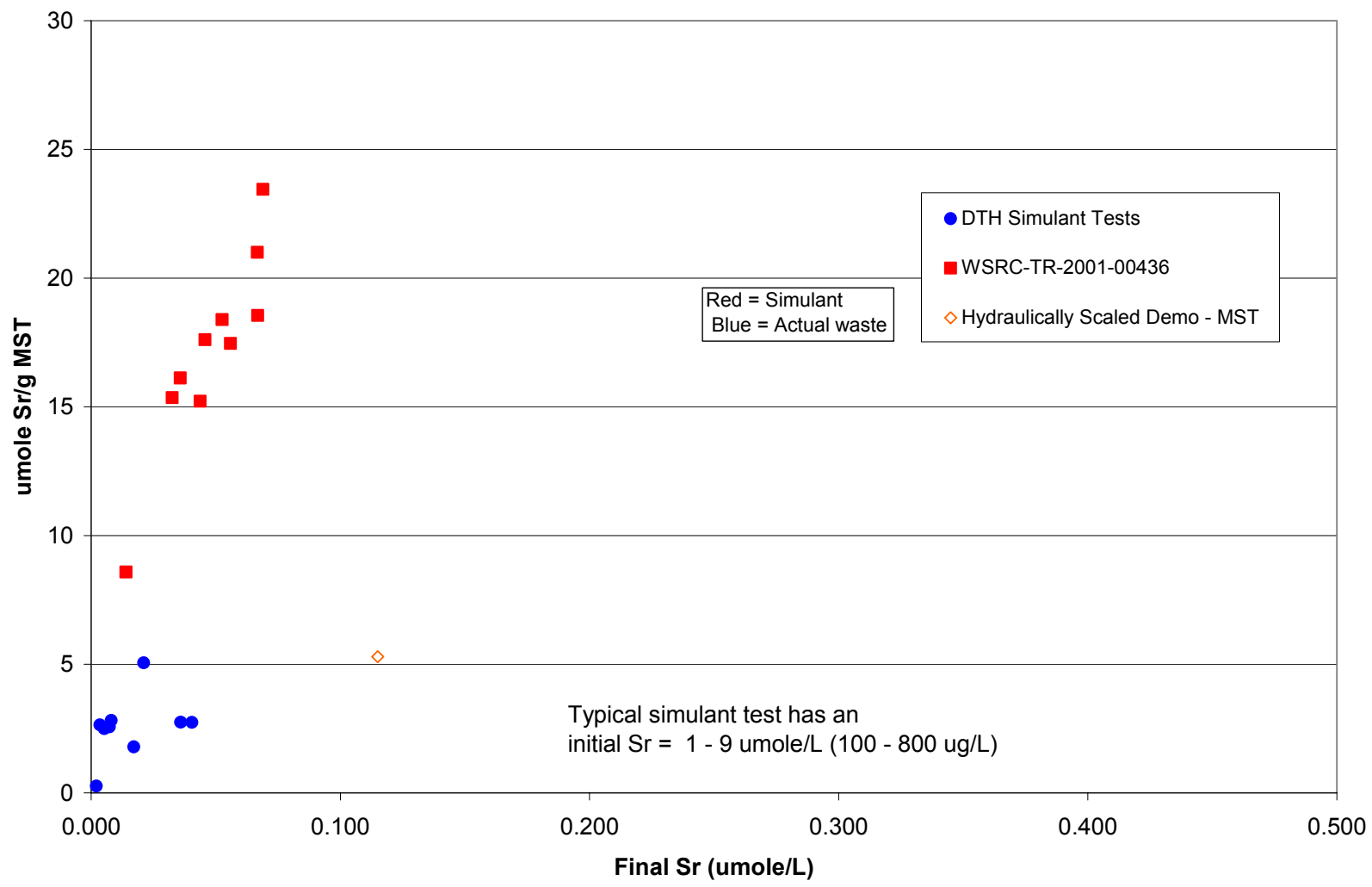


WSRC-TR-2002-00355

\subsection{Conclusions}

We completed a series of demonstrations to further understand the abilities of MST and permanganate to remove actinides and strontium from high level waste. From these tests, we draw the following conclusions.

- Plutonium and strontium removal by MST from experiments using simulated and actual waste at volumes from 0.1 to $70 \mathrm{~L}$ and with varying degrees of mixing - from none to fully turbulent - show consistency when evaluated as conventional sorption isotherms. Demonstrations hydraulically scaled to match mixing conditions of the Actinide Removal Process behave consistently with laboratory experiments using orbital shakers. Hence, the complete historical data set provides a reliable basis for predicting behavior within larger equipment.

- Demonstrations hydraulically scaled to match mixing conditions of the Actinide Removal Process indicate suspension of MST at expected initial operating conditions (i.e., concentrations), but in the absence of sludge. We expect similar suspension with sludge present but recommend additional testing to confirm.

- Strontium removal by MST addition in actual waste demonstrations proved marginal in two demonstrations, failing to meet process requirements for the Salt Waste Processing Facility $(40 \mathrm{nCi} / \mathrm{g})$ in one instance using samples from Tank $37 \mathrm{H}$. We lack a complete understanding of this poor performance, but we believe at this time the weak strontium performance is due to the poor quality of the batch of MST used.

- The use of permanganate showed better removal of strontium than observed for MST in a comparable experiment. The plutonium data contained large variances making a conclusion regarding relative performance to MST impossible. 


\subsection{Acknowledgements}

The authors wish to acknowledge the great amount of work done by many of the staff and technicians, both in the High Activity Cells and in B-Wing. In particular, Jane Johnson, Lucy Beasley and Alda Coleman provided help with the test apparatus in the shielded cells. Carolyn Conley and Ron Blessing provided additional support in the shielded cells. Mona Blume, Henry Bolton, Lin Thacker and Kim Prettel performed experiments with simulated and radiotraced actual waste. Cecilia DiPrete, David DiPrete, Yvonne Tilley, Dan Walker, Marilyn Thompson, Robin Wainwright, Beverly Adams, Gina Robbins, Kathy Smith and Teresa Eddy provided sample results from the radiocounting facility. Bill Boyce, Pam Waller, Neta Rutland and Mira Malek provided ICP-MS results. 
WSRC-TR-2002-00355

\subsection{Quality Assurance}

The work complies with the following plan: T. B. Peters, D. D. Walker, M. A. Norato, and S. D. Fink, "Task Technical and Quality Assurance Plan for Larger-Scale (50 to 100-L) Demonstrations of Strontium and Actinide Removal in Actual Waste using Monosodium Titanate and Permanganate" WSRC-RP-2002-00145, Rev.0, March 12, 2002. Laboratory results are kept in lab notebook WSRC-NB-2002-00053. 
WSRC-TR-2002-00355

\section{Appendix 1. MST Qualification Tests.}

We analyzed the TNX batch of material before use and found it to contain $16.5 \mathrm{wt} \%$ MST solids.

\section{TNX MST Qualification Tests}

${ }^{85} \mathrm{Sr}$ Qualification: $50 \mathrm{uL}$ of a ${ }^{85} \mathrm{Sr}$ tracer was pipetted into $500 \mathrm{~mL}$ of a standard salt solution. The contents of the vessel were mixed thoroughly. A $100 \mathrm{~mL}$ portion of this material was removed and placed into a separate vessel. A sample from this vessel was analyzed with a gamma counter to determine the feed activity of the ${ }^{85} \mathrm{Sr} .0 .4 \mathrm{~g} / \mathrm{L}$ of the TNX MST was then added to the contents of the vessel. Filtered samples from this vessel were taken at 24 and 48 hours and analyzed for ${ }^{85} \mathrm{Sr}$ content. This test was repeated two more times. The results are listed below. A DF of 150 or greater is considered acceptable.

\begin{tabular}{|c|c|c|c|}
\hline Test & A & B & C \\
\hline $\begin{array}{c}\text { Wt. of MST slurry } \\
(\mathrm{g})\end{array}$ & $0.2203 \mathrm{~g}$ & 0.2294 & 0.2122 \\
\hline $\begin{array}{c}\text { Volume of Salt } \\
\text { Solution (mL) }\end{array}$ & 93.4072 & 97.2656 & 89.9728 \\
\hline Background & 18 & 18 & 13 \\
\hline Feed * & 57846 & 59268 & 58146 \\
\hline 24 hour samples * & 992 & 960 & 922 \\
\hline 48 hour samples * & 929 & 923 & 924 \\
\hline 24 hour DF & 58.3 & 61.7 & 63.1 \\
\hline
\end{tabular}

* Units are counts $/ 10$ minute counting for a $3 \mathrm{~mL}$ sample.

Particle Size Qualification: A small sample of the TNX MST was run on a MicroTrac apparatus. The results are listed below. "\% Pass" is the percentage of the particles that pass the size filter (result to the left). 
WSRC-TR-2002-00355

\begin{tabular}{|c|c|c|c|}
\hline Size (microns) & \% Pass & Size (microns) & \%Pass \\
\hline 704.0 & 100.00 & 22.00 & 74.58 \\
\hline 497.8 & 100.00 & 15.56 & 65.54 \\
\hline 352.0 & 100.00 & 11.00 & 57.57 \\
\hline 248.9 & 99.93 & 7.778 & 51.34 \\
\hline 176.0 & 99.04 & 5.500 & 43.27 \\
\hline 124.5 & 97.80 & 3.889 & 31.72 \\
\hline 88.00 & 94.95 & 2.750 & 20.34 \\
\hline 62.23 & 91.17 & 1.945 & 10.67 \\
\hline 44.00 & 86.78 & 1.375 & 5.12 \\
\hline 31.11 & 81.40 & 0.972 & 1.29 \\
\hline
\end{tabular}

To qualify in particle size, the MST must possess $<1 \%$ particles that are less than 1 micron in size and possess $<1 \%$ particles that are greater than 35.5 microns in size. 
Appendix 2. ICP-MS Results for the Original Tank 37H Solution.

\begin{tabular}{|l|c|}
\hline \multicolumn{1}{|c|}{ Mass } & Result (ppm) \\
\hline 231 & $\leq 0.01944$ \\
\hline 232 & 0.1390 \\
\hline 233 & $\leq 0.01944$ \\
\hline 234 & $\leq 0.01944$ \\
\hline 235 & 0.06124 \\
\hline 236 & 0.02722 \\
\hline 237 & $\leq 0.01944$ \\
\hline 238 & 0.6658 \\
\hline 239 through 247 & $\leq 0.01944$ each \\
\hline
\end{tabular}


WSRC-TR-2002-00355

\section{Appendix 3. Engineering Calculations for the ARP Type Reactor.}

\section{Background:}

We examined whether the existing Filter Feed Tank (FFT) configuration and mixing efficiency in the Late Wash Facility in Building 512-S is sufficient to perform MST strikes for the Actinide Removal Process (ARP) for HLW supernate solution being prepared for solvent extraction.

To this end, we performed a mixing test in a scaled-down version of the FFT to determine the performance in suspending/dispersing MST.

The goal here is not to optimize performance, but to reproduce conditions in the FFT and observe the resulting behavior.

\section{FFT:}

- Nominal 6450 gallons, $12 \mathrm{ft}$ ID $\times$ 91.5" side with sloped bottom at 3/8" per foot of slope.

- 4 baffles at $90^{\circ}$ apart.

- No internal cooling coil.

- One agitation speed of $68 \mathrm{rpm}$.

- Two sets of 36 " diameter impellers.

- Top impeller is 4-blade at $45^{0}$ pitch.

- Bottom impeller is 4-blade Rushton type turbine.

Impeller diameter-to-tank diameter ratio $=D / T=3 \mathrm{ft} / 12 \mathrm{ft}=\underline{0.25}$

Figure 2 shows a total "fluid" height $=Z=87.0$ "

So, $Z / T=87.0 " / 144 "=\underline{0.60}$

$Z / T<1.0$, so the tank does not need two impellers. But two impellers are currently in place, and this will enhance mixing.

\section{WPT Mock-up:}

- Tank diameter (ID) is $42.4 \mathrm{~cm}$

- Minimum height is $29 \mathrm{~cm}$ with bottom slope identical to FFT.

- 4 baffles at $90^{\circ}$ apart.

- A single $12.7 \mathrm{~cm}$ (5") diameter marine propeller type impeller, to be mounted at Z/3 from the bottom of the tank.

$D=5 "=12.7 \mathrm{~cm}$

$D / T=12.7 \mathrm{~cm} / 42.4 \mathrm{~cm}=0.299 \cong \underline{0.30}$

In this tank, bottom slope is only 0.52" over entire tank diameter. Therefore, we can ignore the bottom slope. The expected fluid height is $22.8 \mathrm{~cm}$. So, 
WSRC-TR-2002-00355

$Z / T=22.8 \mathrm{~cm} / 42.4 \mathrm{~cm}=\underline{0.54}$

\section{Fluid Properties:}

This corresponds to approximately $32 \mathrm{~L}$ of fluid.

Estimated fluid density, $\rho \cong 1.2 \mathrm{~g} / \mathrm{cm}^{3}$.

Estimated fluid viscosity, $\mu \cong 3 c P$.

As the FFT has two impellers and the tank used in these experiments has only one, a straight-forward comparison is not possible. So, we will seek to reproduce the conditions in the "worst case scenario" in the FFT - i.e., reproduce the lowest FFT bulk fluid velocities in the laboratory vessel.

From the attached FLUENT figure (Figure 26), we estimate that the lowest bulk velocity an MST particle would "see" in the FFT is approximately $0.3 \mathrm{ft} / \mathrm{s}$.

Also, in FFT estimate the impeller Reynolds Number, $N_{R e}$, for agitation speed of 68 rpm (1.13 rps).

$D=36 "=91.44 \mathrm{~cm}$

$$
\begin{aligned}
& N_{\mathrm{Re}}=\frac{\left(1.13 \mathrm{~s}^{-1}\right)(91.44 \mathrm{~cm})^{2}\left(1.2 \mathrm{~g} / \mathrm{cm}^{3}\right)}{0.03 \mathrm{~g} / \mathrm{cm} \mathrm{s}} \\
& =N_{R e}=\underline{3.8 \times 10^{5}} \Rightarrow \text { Turbulent Regime }
\end{aligned}
$$

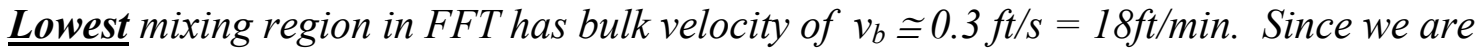
interested in duplicating performance for solids suspension purposed, we want the same bulk velocity in the laboratory tank.

To determine the proper agitation speed, we must first determine pumping capacity, $Q$, for the laboratory vessel.

$$
Q=v_{b} A_{c s}
$$

Where $A_{c s}=\pi D^{2} / 4=\pi(1.39 f t)^{2} / 4=1.52 f t^{2}$

Therefore,

$Q=(18 \mathrm{ft} / \mathrm{min})\left(1.52 \mathrm{ft}^{2}\right)=\underline{27.4 \mathrm{ft}^{3} / \mathrm{min}}$

Based on our estimated $N_{R e}$ for the FFT, we will assume turbulent mixing so, the Pumping Number, $N_{Q}$, is constant with respect to $N_{R e}$.

From Figure 2 of Hicks, et al. ${ }^{22}$, for $D / T=0.3$ (in WPT vessel), $N_{Q} \cong \underline{0.78}$ Now we must solve for the agitation speed, $N$ (rpm). 
WSRC-TR-2002-00355

$$
N=\frac{Q}{N_{Q} D^{3}}=\frac{27.4}{(0.78)(0.417)^{3}}=\underline{484 \mathrm{rpm}},
$$

(where $D$ is in $f t, 5 ”=0.417 f t$ )

Now we solve for $N_{R e}$ based on the above agitation speed and verify that it yields the proper $N_{Q}$ from Figure 2 in Hicks, et al. ${ }^{22}$

$$
N_{\mathrm{Re}}=10.7 \frac{D^{2} N S_{g}}{\mu}
$$

Where $S_{g}$ is specific gravity of liquid $=1.2$ and $D$ is in inches.

$$
N_{R e}=10.7(5)^{2}(484)(1.2) / 3=\underline{5.2 \times 10^{4}}
$$

From Figure 2 in Hicks, et al. ${ }^{22}$, this $N_{R e}$ yields an $N_{Q} \cong 0.78$, So our calculated value of $N$ is correct. Therefore, the necessary agitation speed, $N=\underline{484 \mathrm{rpm}}$. 
WSRC-TR-2002-00355

Figure 26. FLUENT Diagram of Bulk Velocity Calculations
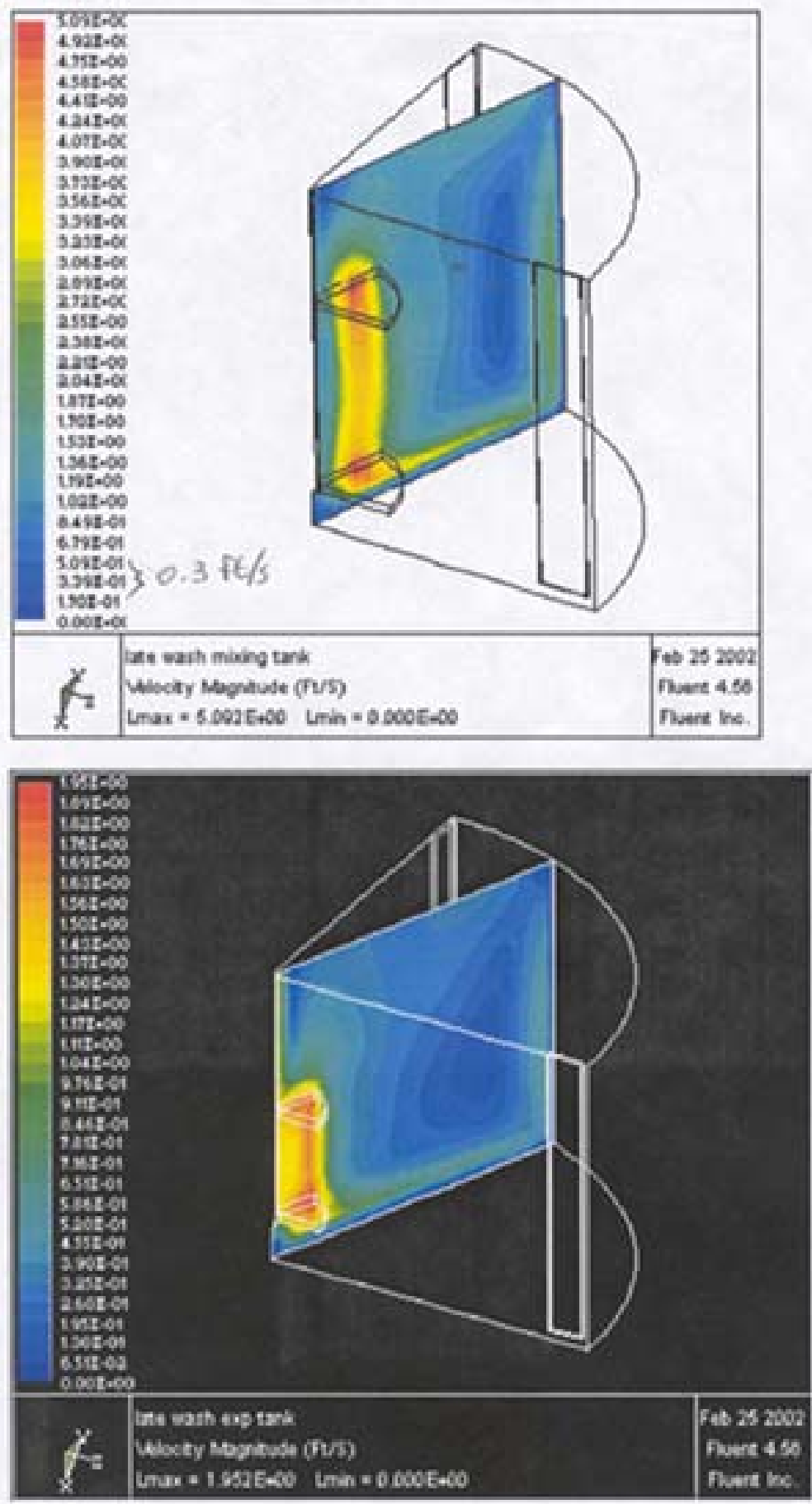

The exp tank is not fully converged, but you get the idea. They look about the same. It will converge, I was just playing with some stuff and ran out of time. 
WSRC-TR-2002-00355

\section{Appendix 4. Mass Data Used in Isotherm Calculations.}

For calculations involving the isotherm graphs, the mass of the elements in question is required. Data from this document used in the isotherm graph is presented here.

Plutonium Mass Data for the Tank 37H/44F MST Strike

\begin{tabular}{|c|c|c|c|}
\hline Time (hours) & $238 \mathrm{Pu}($ umole/ $/ \mathrm{L})$ & $239 / 240 \mathrm{Pu}($ umole $/ \mathrm{L})$ & Total Pu (umole/L) \\
\hline 0 (just before MST addn) & $9.96 \mathrm{E}-05$ & $3.96 \mathrm{E}-03$ & $4.06 \mathrm{E}-03$ \\
\hline 1 & $7.33 \mathrm{E}-05$ & $1.11 \mathrm{E}-03$ & $1.18 \mathrm{E}-03$ \\
\hline 2 & $7.89 \mathrm{E}-05$ & $2.48 \mathrm{E}-03$ & $2.56 \mathrm{E}-03$ \\
\hline 3 & $4.16 \mathrm{E}-05$ & $1.08 \mathrm{E}-03$ & $1.12 \mathrm{E}-03$ \\
\hline 8 & $5.35 \mathrm{E}-05$ & $1.19 \mathrm{E}-03$ & $1.24 \mathrm{E}-03$ \\
\hline 12 & $4.37 \mathrm{E}-05$ & $1.19 \mathrm{E}-03$ & $1.23 \mathrm{E}-03$ \\
\hline 24 & $3.74 \mathrm{E}-05$ & $7.93 \mathrm{E}-04$ & $8.31 \mathrm{E}-04$ \\
\hline 30 & $6.46 \mathrm{E}-05$ & $2.03 \mathrm{E}-03$ & $2.10 \mathrm{E}-03$ \\
\hline
\end{tabular}

Total Plutonium Concentrations in the Large Scale MST Demonstration Filtrate

\begin{tabular}{|c|c|c|c|}
\hline Time (hours) & $238 \mathrm{Pu}($ umole $/ \mathrm{L})$ & $239 / 240 \mathrm{Pu}($ umole $/ \mathrm{L})$ & Total $\mathrm{Pu}$ (umole $/ \mathrm{L}$ ) \\
\hline 0 (before MST addition) & $1.08 \mathrm{E}-05$ & 0.015323 & 0.015334 \\
\hline 2 & $4.72 \mathrm{E}-06$ & 0.00496 & 0.004965 \\
\hline 4 & $4.18 \mathrm{E}-06$ & 0.005393 & 0.005397 \\
\hline 12 & $4.56 \mathrm{E}-06$ & 0.004554 & 0.004559 \\
\hline 18 & $3.23 \mathrm{E}-06$ & 0.003679 & 0.003682 \\
\hline 24 & $2.97 \mathrm{E}-06$ & 0.00393 & 0.003933 \\
\hline 30 & $3.32 \mathrm{E}-06$ & 0.003561 & 0.003565 \\
\hline
\end{tabular}

Strontium-85 and -88 Concentrations in the Large Scale MST Demonstration Filtrate

\begin{tabular}{|c|c|c|}
\hline Time (hours) & ${ }^{85} \mathrm{Sr}($ umole/L) & ${ }^{88} \mathrm{Sr}$ (umole/L) \\
\hline 0 (before MST addition) & $7.43 \mathrm{E}-06$ & $1.93 \mathrm{E}+00$ \\
\hline 2 & $3.37 \mathrm{E}-07$ & $2.00 \mathrm{E}-01$ \\
\hline 4 & $4.09 \mathrm{E}-07$ & $1.58 \mathrm{E}-01$ \\
\hline 12 & $2.98 \mathrm{E}-07$ & $1.25 \mathrm{E}-01$ \\
\hline 18 & $2.60 \mathrm{E}-07$ & $1.62 \mathrm{E}-01$ \\
\hline 24 & $2.62 \mathrm{E}-07$ & $1.43 \mathrm{E}-01$ \\
\hline 30 & $2.75 \mathrm{E}-07$ & $1.48 \mathrm{E}-01$ \\
\hline
\end{tabular}


WSRC-TR-2002-00355

\section{Appendix 5. Plutonium Data Analysis for the Permanganate Large Scale Demonstration.}

For the permanganate Large Scale Demonstration, researchers analyzed the filtered solutions for total plutonium $\left({ }^{238} \mathrm{Pu}+{ }^{239 / 240} \mathrm{Pu}\right)$. Table 31 shows these plutonium results while Figure 27 shows the graphical results.

Table 31. Total Plutonium in the $\mathrm{MnO}_{4}$ Demonstration Filtrate

\begin{tabular}{|c|c|c|c|c|}
\hline & Experiment & Experiment & Control & Control \\
\hline Time (hours) & $238 \mathrm{Pu}(\mathrm{nCi} / \mathrm{g})$ & $239 / 40 \mathrm{Pu}(\mathrm{nCi} / \mathrm{g})$ & $238 \mathrm{Pu}(\mathrm{nCi} / \mathrm{g})$ & $239 / 40 \mathrm{Pu}(\mathrm{nCi} / \mathrm{g})$ \\
\hline $0^{*}$ & 0.0951 & 2.09 & 0.0473 & 0.981 \\
\hline 2 & 0.0752 & 1.61 & 0.0732 & 1.39 \\
\hline 4 & 0.271 & 1.65 & 0.0964 & 2.06 \\
\hline 12 & 0.0567 & 1.34 & 0.0968 & 2.44 \\
\hline 18 & 0.0634 & 1.25 & 0.0468 & 1.06 \\
\hline 24 & 0.0520 & 1.29 & 0.0606 & 1.05 \\
\hline 30 & 0.0732 & 1.28 & 0.0431 & 0.908 \\
\hline
\end{tabular}

$*$ The time $=0$ data are before the $\mathrm{MnO}_{4} / \mathrm{H}_{2} \mathrm{O}_{2}$ addition.

Figure 27. Total Plutonium in the $\mathrm{MnO}_{4}$ Demonstration Filtrate

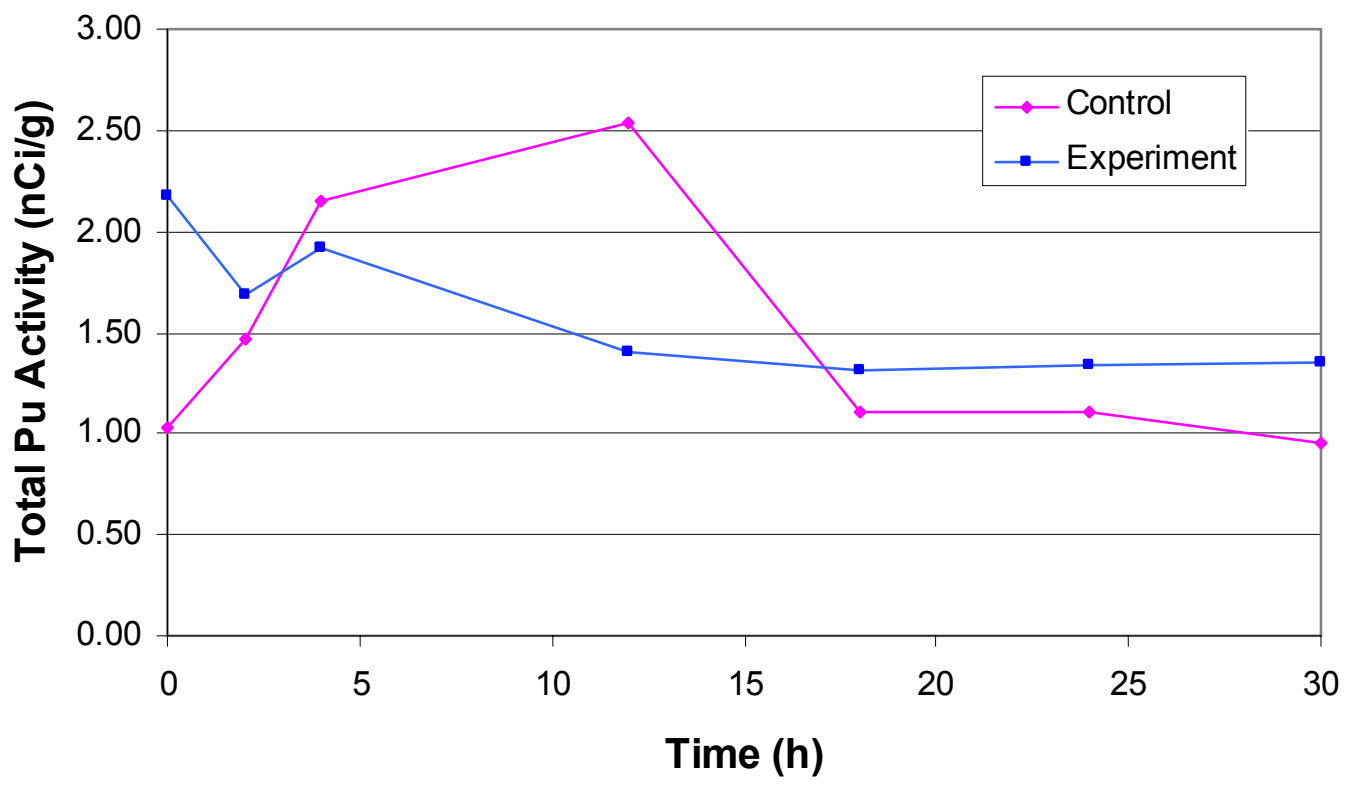


WSRC-TR-2002-00355

The results show a non-intuitive behavior. While the experimental data would indicate a DF of 1.6, the control data is nonsensical. Analytical uncertainty is not the cause of this problem. On the assumption that the samples suffered from contamination or from human error, SRTC decided to pull a new set of samples from archival material (retained throughout the experiment and filtered before storage). The results of these new samples are displayed in Table 32 and Figure 28.

Table 32. Total Plutonium in the $\mathrm{MnO}_{4}$ Demonstration Filtrate

\begin{tabular}{|c|c|c|c|c|}
\hline & Experiment & Experiment & Control & Control \\
\hline Time (hours) & $238 \mathrm{Pu}(\mathrm{nCi} / \mathrm{g})$ & $239 / 40 \mathrm{Pu}(\mathrm{nCi} / \mathrm{g})$ & $238 \mathrm{Pu}(\mathrm{nCi} / \mathrm{g})$ & $239 / 40 \mathrm{Pu}(\mathrm{nCi} / \mathrm{g})$ \\
\hline $0^{*}$ & 0.0536 & 1.24 & $<0.0948$ & 0.953 \\
\hline 2 & 0.0877 & 1.74 & 0.0202 & 1.00 \\
\hline 4 & 0.0621 & 1.62 & 0.110 & 1.86 \\
\hline 12 & 0.0648 & 1.30 & 0.165 & 3.99 \\
\hline 18 & 0.0563 & 1.33 & 0.0502 & 0.873 \\
\hline 24 & 0.0459 & 1.19 & 0.0481 & 0.903 \\
\hline 30 & 0.0499 & 1.21 & $<0.0936$ & 0.943 \\
\hline
\end{tabular}

* The time $=0$ data are before the $\mathrm{MnO}_{4} / \mathrm{H}_{2} \mathrm{O}_{2}$ addition.

Figure 28. Total Plutonium in the $\mathrm{MnO}_{4}$ Demonstration Filtrate (new samples)

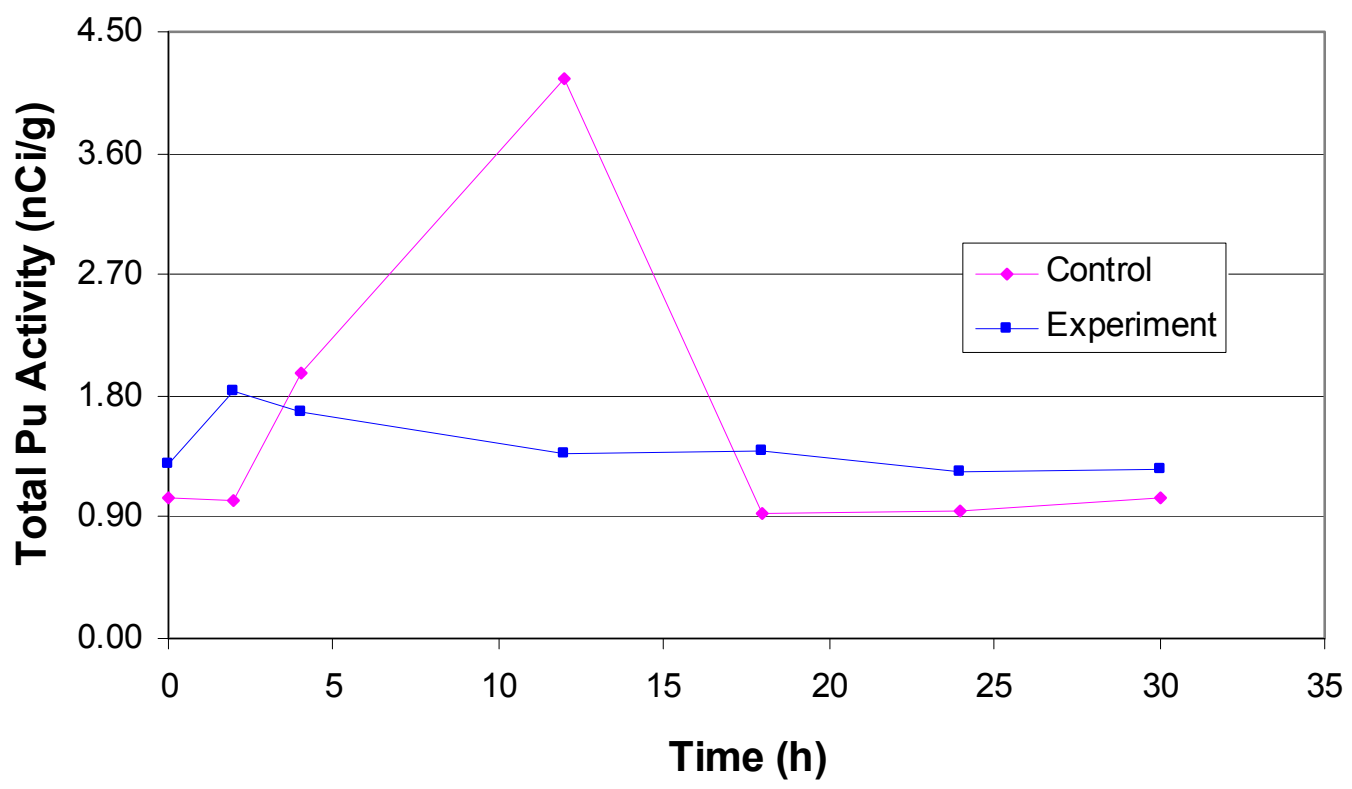


WSRC-TR-2002-00355

This new set of analyses did not improve our understanding of the plutonium chemistry. We have been able to discard insufficient acidification time as the cause of this sample variability since all samples were allowed to digest for $\sim 24$ hours before analysis. Analytical uncertainty also does not appear to be the issue.

Finally, the researchers decided to re-examine the last set of submitted samples for evidence of insoluble plutonium or colloidal plutonium. If this material is passing through the filtration during sampling then this might account for the variable plutonium results. We recovered the previous set of samples and, to each of them, added a mixture of nitric and hydrofluoric acid. This combination of acids would dissolve any insoluble plutonium solids. We submitted the acidified samples for analysis. Table 33 shows these plutonium results while Figure 29 shows the graphical results.

Table 33. Plutonium Concentrations in the $\mathrm{MnO}_{4}$ Demonstration Filtrate after Reacidifaction

\begin{tabular}{|c|c|c|c|c|}
\hline & Experiment & Experiment & Control & Control \\
\hline Time (hours) & $238 \mathrm{Pu}(\mathrm{nCi} / \mathrm{g})$ & $239 / 40 \mathrm{Pu}(\mathrm{nCi} / \mathrm{g})$ & $238 \mathrm{Pu}(\mathrm{nCi} / \mathrm{g})$ & $239 / 40 \mathrm{Pu}(\mathrm{nCi} / \mathrm{g})$ \\
\hline $0^{*}$ & 0.0638 & 1.16 & 0.0755 & 0.797 \\
\hline 2 & 0.0933 & 1.48 & 0.0264 & 1.15 \\
\hline 4 & 0.0463 & 1.37 & 0.148 & 2.02 \\
\hline 12 & 0.0538 & 1.45 & 0.210 & 4.33 \\
\hline 18 & 0.0670 & 1.32 & 0.0362 & 0.929 \\
\hline 24 & 0.0736 & 1.32 & 0.0390 & 0.810 \\
\hline 30 & 0.0454 & 1.41 & 0.0362 & 0.839 \\
\hline
\end{tabular}

* The time $=0$ data are before the $\mathrm{MnO}_{4} / \mathrm{H}_{2} \mathrm{O}_{2}$ addition. 
WSRC-TR-2002-00355

\section{Figure 29. Plutonium Concentrations in the $\mathrm{MnO}_{4}$ Demonstration Filtrate after Reacidifaction}

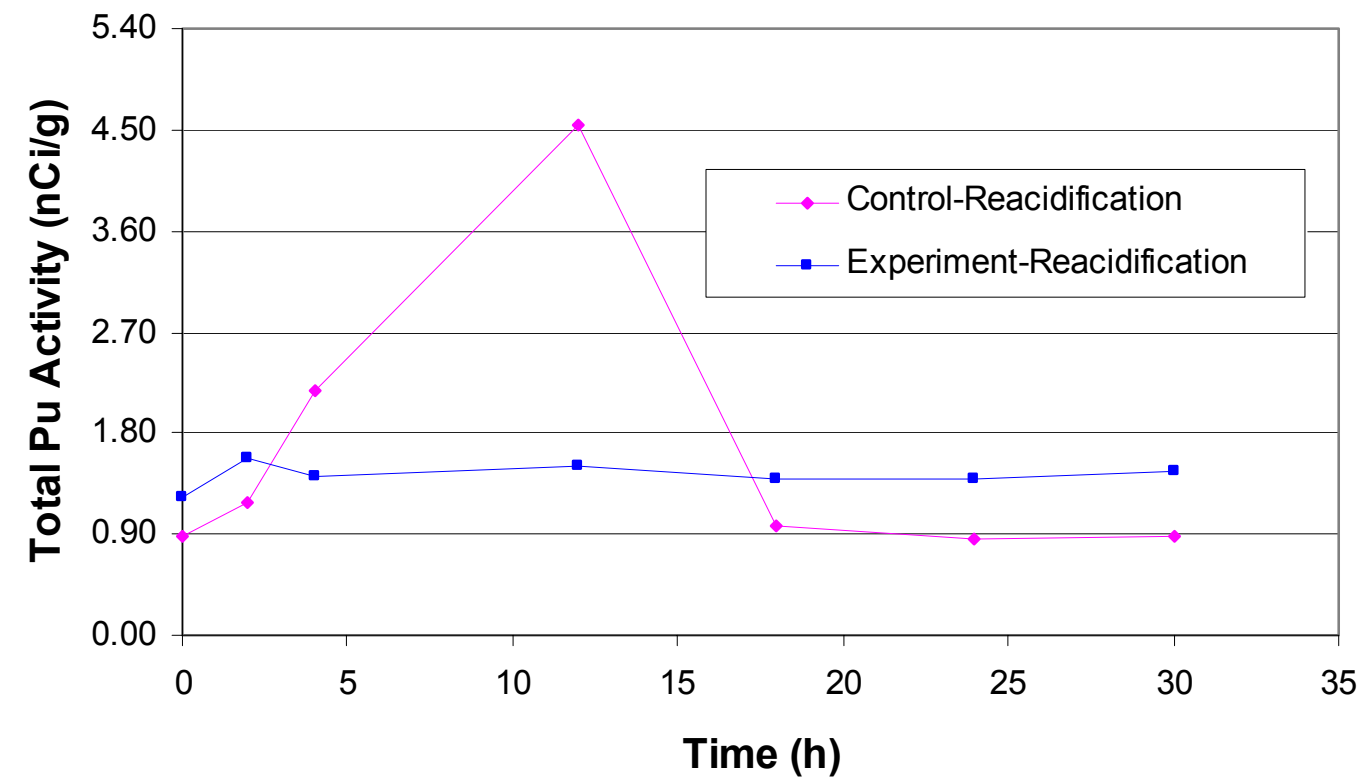

The results of this final analysis indicate that insoluble plutonium from the archive samples does not apparently cause the variable plutonium results.

At this time we hypothesize that the variability in the experimental data resulted from dissolution of variable amounts of the insoluble plutonium in the reactor coming into solution during the experiment by the oxidative action of the permanganate. We know that insoluble plutonium exists from the fact the equilibrium solution concentrations of plutonium are less than we knowingly added. We also know that permanganate is a powerful oxidizing agent. Previous work by Barnes ${ }^{23}$ indicates similar behavior in those tests. In that case, evidence for both neptunium and plutonium solubilization exists.

Finally, the control results cannot be attributed to this theory. The control bottle did not see any permanganate. The only other factor that could contribute to the variable control results is contamination received in the hoods. Unfortunately we lacked sufficient funds to confirm these theories. 
WSRC-TR-2002-00355

\subsection{References}

${ }^{1}$ D. T. Hobbs and D. D. Walker, "Plutonium and Uranium Adsorption on Monosodium Titanate," WSRC-RP-92-93, August 13, 1992.

${ }^{2}$ D. T. Hobbs and S. D. Fleischman, "Fissile Solubility and Monosodium Titanate Loading Tests," WSRC-RP-92-1273, Rev. 0, February 12, 1993.

${ }^{3}$ M. J. Barnes, D. T. Hobbs, M. C. Duff, and S. D. Fink, "Strontium and Actinides Removal from Savannah River Site Actual Waste Samples by Freshly Precipitated Manganese Oxide," WSRC-TR-2002-00048, Rev. 2, August 12, 2002.

${ }^{4}$ M. G. Bronikowski, D. T. Hobbs, and W. R. Wilmarth, "Preliminary Report on Monosodium Titanate Adsorption Kinetics," WSRC-TR-98-00347, Rev. 0, October 5, 1998.

${ }^{5}$ D. T. Hobbs, M. G. Bronikowski, T. B. Edwards, and R. L. Pulmano, "Final Report on Monosodium Titanate Adsorption Kinetics," WSRC-TR-99-0134, Rev. 0, May 28, 1999.

${ }^{6}$ D. T. Hobbs and R. L. Pulmano, "Phase IV Simulant Testing of Monosodium Titanate Adsorption Kinetics,” WSRC-TR-99-0219, Rev. 0, June 29, 1999.

${ }^{7}$ D. T. Hobbs and R. L. Pulmano, "Phase IV Testing of Monosodium Titanate Adsorption Kinetics with Radioactive Waste," WSRC-TR-99-00286, Rev. 0, September 3, 1999.

${ }^{8}$ R. A. Dimmena, H. H. Elder, J. R. Fowler, R. C. Fowler, M. V. Gregory, T. Hang, R. A. Jacobs, P. K. Paul, J. A. Pike, P. L. Rutland, F. G. Smith III, S. G. Subosits, G. A. Taylor and S. G. Campbell, "Bases, Assumptions, and Results of the Flowsheet Calculations for the Short List Salt Disposition Alternatives," WSRC-RP-99-00006, Rev. 3, May 2001.

${ }^{9}$ D. T. Hobbs, M. S. Blume and H. L. Thacker, "Phase V Simulant Testing of Monosodium Titanate Adsorption Kinetics," WSRC-TR-2000-00142, Rev. 0, May 24, 2000 .

${ }^{10}$ D T. Hobbs, "Evaluation of Alternate Materials and Methods for Strontium and Alpha Removal from Savannah River Site High Level Waste Solutions," WSRC-TR-200000229, Rev. 0, August 2000.

${ }^{11}$ H. H. Elder, "Salt Blending Basis for Revision 12 of the HLW System Plan," HLW SDT-2001-00146, Rev. 0, April 26, 2001.

${ }^{12}$ S. D. Fink, D. T. Hobbs, and T. B. Peters, "Demonstration of MST Efficacy on Removal of Actinides and Strontium in "Bounding Alpha" Waste," WSRC-TR-200200555, Rev. 0, December 17, 2002. 
WSRC-TR-2002-00355

${ }^{13}$ D. T. Hobbs, "Determination of the Equilibrium Distribution Constant for Monosodium Titanate Samples", WSRC L21.1, Procedure IWT-OP0033, Rev. 3, April 30, 1997.

${ }^{14}$ S. G. Campbell, M. W. Geeting, M. L. Crowder, G. F. Kessinger, M. A. Norato, R. A. Pierce, and D. D. Walker, "High Level Waste Demonstration of the Caustic-Side Solvent Extraction Process With Optimized Solvent in the 2-Cm Centrifugal Contactor Apparatus Using Tank 37H/44F Supernate", WSRC-TR-2002-00243, Rev. 0, November 1, 2002.

${ }^{15}$ C. J. Martino, M. R. Poirier, F. F. Fondeur, and S. D. Fink, "Flocculating, Settling, and Decanting for the Removal of Monosodium Titanate and Simulated High-Level Waste Sludge from Simulated Salt Supernate,”WSRC-TR-2001-00413, October 16, 2001.

${ }^{16}$ M. A. Norato, S. D. Fink, F. F. Fondeur, G. F. Kessinger, R. A. Pierce, and D. D. Walker, "Demonstration of Caustic-Side Solvent Extraction with Optimized Solvent in the 2-Cm Cetrifugal Contactor Apparatus Using Dissolved Salt Cake from Tank 37H", WSRC-TR-2002-00307, Rev. 1, September 3, 2002.

${ }^{17}$ S. D. Fink, D. T. Hobbs, and M. R. Poirier, "Status Assessment of Readiness to Deploy Permanganate Treatment for Removal of Strontium and Actinides from Savannah River Site High Level Waste,” WSRC-TR-2002-00524, Rev. 0, September 23, 2002.

${ }^{18}$ S. G. Subosits, S. G. Campbell, "Alpha Removal/Caustic Side Solvent Extraction Material Balance Calculations with Monosodium Titanate and Sodium Permanganate Alternatives", HLW-PRE-2002-0019, Rev. 0, July 24, 2002.

${ }^{19}$ M. C. Duff, D. T. Hobbs, and S. D. Fink, "Permanganate Treatment Optimization Studies for Strontium and Actinide Removal from High Level Waste Simulants", WSRCTR-2002-00027, Rev. 0, January 12, 2002.

${ }^{20}$ R. A. Dewberry, "Procedure for Cs-137 Removal by Cation Exchange", DPST-88-514, June 10, 1988.

${ }^{21}$ M. R. Poirier, F. F. Fondeur, T. L. Fellinger, S. D. Fink, "Cross-Flow Filtration Demonstration for Slurries Containing High Level Waste Sludge and Monosodium Titanate", WSRC-TR-2001-00212, April 11, 2001

${ }^{22}$ R. W. Hicks, J. R. Morton, and J. G. Fenic, "How to Design Agitators for Desired Process Response," Chemical Engineering, April 26, 1976. pp 102-110.

${ }^{23}$ See section 4.1.1.3, and Figure 17 and associated text in particular. See reference 3. 